IRA-International Journal of Management \& Social Sciences

ISSN 2455-2267; Vol.04, Issue 01 (2016)

Institute of Research Advances

http://research-advances.org/index.php/RAJMSS

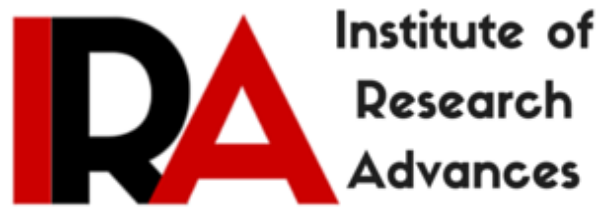

\title{
The Implementation of COP21 Agreement in the Third World
}

Jan-Erik Lane

Fellow with Public Policy Institute, Belgrade

10 Charles Humbert, 1205 Geneva, Switzerland.

DOI: http://dx.doi.org/10.21013/jmss.v4.n1.p22

\section{How to cite this paper:}

Lane, J. (2016). The Implementation of COP21 Agreement in the Third World. IRAInternational Journal of Management \& Social Sciences (ISSN 2455-2267), 4(1). http://dx.doi.org/10.21013/jmss.v4.n1.p22

(C) Institute of Research Advances

(cc) EY-NO

This works is licensed under a Creative Commons Attribution-Non Commercial 4.0 International License subject to proper citation to the publication source of the work.

Disclaimer: The scholarly papers as reviewed and published by the Institute of Research Advances (IRA) are the views and opinions of their respective authors and are not the views or opinions of the IRA. The IRA disclaims of any harm or loss caused due to the published content to any party. 


\begin{abstract}
The so-called Third World must now start developing implementation strategies of the COP21 objectives. In both emerging economies and poor countries, CO2:s area rather high except some countries where CO2:s are very high. Thus, the energy reliance upon coal - wood or solid - as well as petroleum must be transformed somehow. Hydro power requires lots of water, which further global warming may deny - look at Venezuela today. Thus, major investments in wind, solar or/and nuclear power are called for, which will have to be partly financed by the COP21 Super fund. Yet, implementing a major decarbonisation conflicts with the developmental goals of Third World countries whatever they may be: "catch-up", reducing poverty, UN development framework, etc. Implementation theory (Wildavsky, Sabatier) teaches us humbleness about the likelihood of goal fulfillment.
\end{abstract}

Keywords: COP21 objectives, global decarbonisation, Third World countries, fossil fuel dependency, traditional renewables, implementation strategies, "sustainable economy", Stern, Wildavsky, Sabatier, Sachs.

\title{
INTRODUCTION
}

The Third World does not figure prominently in the global debate about $\mathrm{CO} 2$ emissions, with the exception of China and India. However, the $\mathrm{CO} 2$ :s in the various countries is large enough to be counted in the implementation of Cop21, as all countries much fulfill the COP21 goals. The overall environmental degradation in several Third World countries has been much researched: the Amazon, the Titicaca Lake and the Caribbean for instance in Latin America, Lake Chad and the endangered species in Africa as well as the Aral Lake, the pollution of Ganges, Mekong River, Yellow River and the Yangtze as well as the rain forest fires in Indonesia. Now, also the governments of Third World countries have bound themselves to respect the COP21 process for the 21 rst century. It includes the following goal targets:

- Halting C02 emissions by 2018

- Reduce CO2 emissions from 2020

- Achieve CO2:s reduction by $40 \%$ in 2030

- Eliminate fossil fuels as energy sources by second half of 21rst century.

In this paper I will discuss whether these objectives are implementable by the governments of a few selected Third World governments. My argument is that the COP21 implementation will depend upon their country specific energy mix, but such an enormous reduction in emissions is hardly feasible, because it comes into contradiction with other desirable goals, like development.

\section{THEORY: THE OVERALL SITUATION}

The COP21 approach to climate change targets almost exclusively the $\mathrm{CO} 2$ emissions, although the greenhouse gases also comprise the dangerous methane emissions, from gas leakages and meat production (cows, pigs) for example. The methane storage in the tundra and oceans could be released with global warming, increasing the threat to mankind several times over.

We will follow the COP21 and its goal of decarbonisation, meaning reducing fossil fuels as energy sources for economic activities in a broad sense. One must not forget that traditional renewables are also coal products resulting in $\mathrm{CO} 2$ emissions inter alia (wood, peat, charcoal, and dung). Third World countries rely a lot upon wood coal and its derivatives when they are poor.

Figure 1 shows the overall dependency of mankind (per person) upon the energy sources that result in large CO2:s.

FIGURE 1. GDP - Energy consumption per capita 1990-2014 $\left(\mathrm{y}=0,26 ; \mathrm{R}^{2}=0,81\right)$ 
GDP vs. Energy usage per capita $1990-2014$

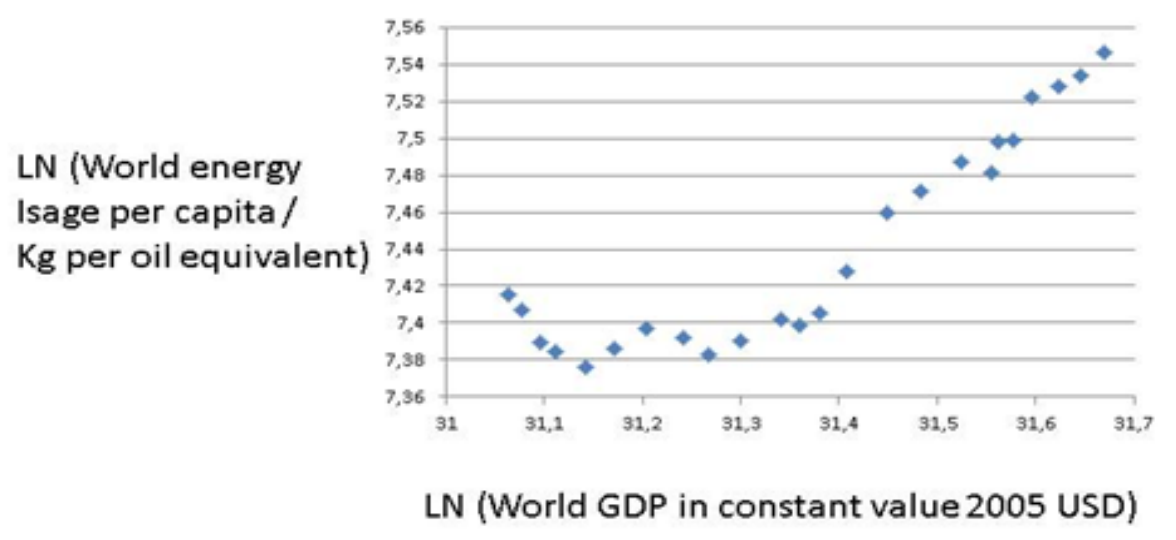

\section{Source: IEA: Key World Energy Statistics}

Although the set of old OECD countries deliver much of the CO2:s, Asia is set of bypass them, especially if Japan and South Korea are placed in the Asian set. Typical of Third World countries is that they have lower $\mathrm{CO}$ :s per capita than the mature economies, but they still must reduce their total emissions, which are sometimes considerable.

The COP21 objectives are for their implementation much impacted by two factors, namely

(1) <GDP-COP link, energy mix>

as they vary from one country to another. The following generalizations about decarbonisation hold starting from the two basic factors <GDP-COP link, energy mix> behind the country variation, to be mapped below:

- The more a country exclusive relies upon coal, the more difficult the COP21 transition

- The more a country relies exclusive upon oil and gas, substituting for coal, the less difficult it is

- The more a country has a diverse energy mix with considerable modern renewables, the better the prospects would be

- The more a country relies upon hydro power and atomic power, the more likely is a successful COP21 transformation

- The more a country relies upon solar, wind or geo-thermal power, the better it is from the point of view of COP21.

We will show with several examples below that emerging and poor Third World countries rely too much upon solids, petroleum and gas for arriving at a successful implementation of COP21.

\section{FINDINGS}

\section{A) Latin America}

Latin America has experienced a period of economic development for a few decades now, resulting in considerable rates of economic growth. It is true that countries have benefited differently from this process, linked with the turn to democracy. But in any case, we may expect to find growing emissions of greenhouse gases, similar to what has been found on the global level and in Asian countries for example. 


\section{a) Total emission 1990}

First, we examine the evidence about total CO2 emissions in 1990 and emissions per capita for 1990 as well. Figure 2 ranks these countries above according to total GDP and total CO2:s in 1990.

FIGURE 2. GDP and CO2 $1990\left(\mathrm{y}=0,99 \mathrm{x}, \mathrm{R}^{2}=0,93\right)$

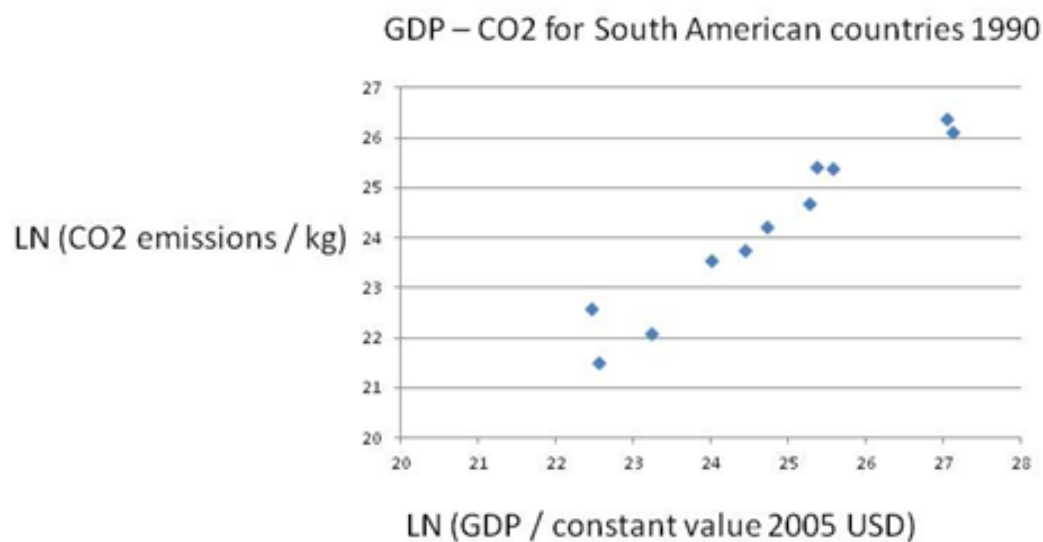

The countries with lowest total emissions of $\mathrm{CO} 2$ were: Paraguay, Uruguay and Bolivia, while the largest emitters included: Mexico, Brazil and Venezuela.

In terms of total $\mathrm{CO} 2$ emissions, the variation between countries stem from their level of economic development. The only exception is Paraguay, where emissions are higher than Bolivia, although the former is more poor than the latter. Most emissions are to be found in the two economic giants, Brazil and Mexico.

\section{b) 1990: Emission/capita}

Let us look at the 1990 emissions per capita, given in Figure 3. The pictures is slightly different from that of total emissions, as population size matters.

Figure 3. GDP/capita - emissions/capita ( $\mathrm{Y}=0,88 \mathrm{x}, \mathrm{R} 2=0,61)$

GDP / capita - CO2 /capita for South American countries 1990

LN (CO2 emissions /

capita, kg)

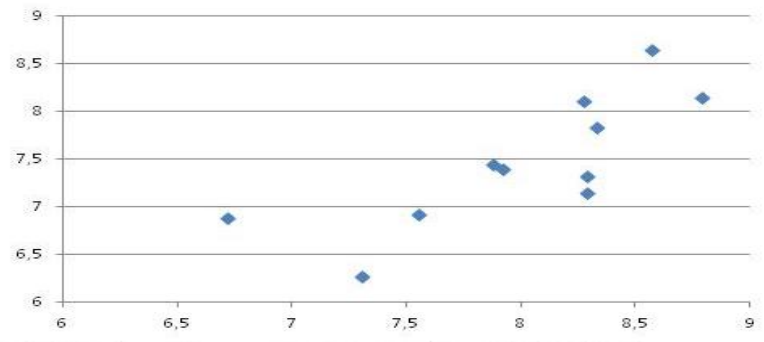

LN (GDP / capita, constant value 2005 USD) 
The per capita emissions of $\mathrm{CO} 2$ goes upwith GDP per capita, but not in a linear fashion. The lowest emissions/capite were to be found in Paraguay, Bolivia and Peru, whereas the highest per capita emissions were to be found in Venezuela, Mexico and Argentina.

\section{c) Total emissions 2014}

In 2014, after 24 of economic development, Latin American coutries have moved up considerably on the GDP scale, reflecting economic advances, especially in some of these countries. However, the missions of $\mathrm{CO} 2$ ave also moved to the right in Figure 4.

FIGURE 4. GDP-COP in Latin America $2014\left(\mathrm{y}=0,9403 \mathrm{x}, \mathrm{R}^{2}=0,9136\right)$

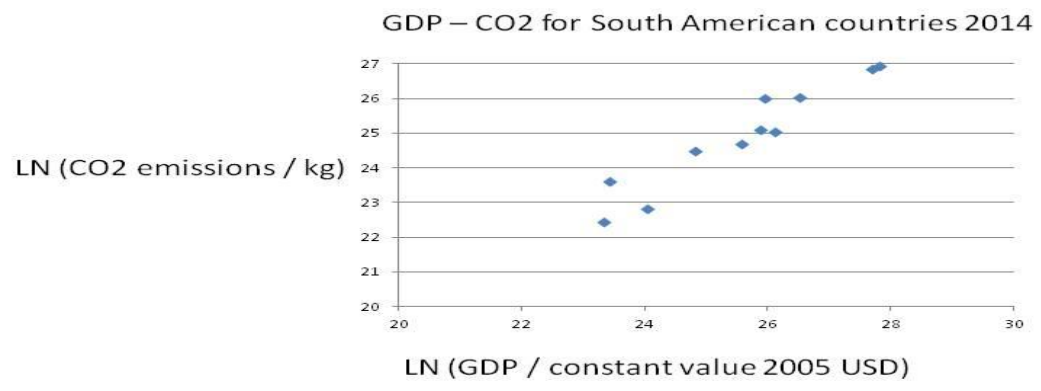

The countries with the lowest total emissions of $\mathrm{CO} 2$ were: Paraguay, Uruguay and Bolivia, while the largest emitters included Brazil, Mexico and Argentina. We have to look especially at Uruguay, scoring surprisingly low with a fairly advanced economy.

The economig progress after 2000 has been conducive to more of $\mathrm{CO} 2$ emissions in all countries selected here. Thus, Latin America faces the same growth-emissions problematic as Asia, namely how to secure economic development while reducing $\mathrm{CO} 2 \mathrm{~s}$, according to $\mathrm{CP} 21$. One must be aware of that total emissions and emissions per capita generate very different country rankings.

It may be intersting also to look at the emissions per capita today (Figure 5).

\section{d) Emissions/capita 2014}

FIGURE 5. 2014: Emissions/capita $\left(y=0,73 x, R^{2}=0,53\right)$ 


\section{GDP / capita - CO2 /capita for South American countries 2014}

\section{LN (CO2 emissions / capita, $\mathrm{kg}$ )}

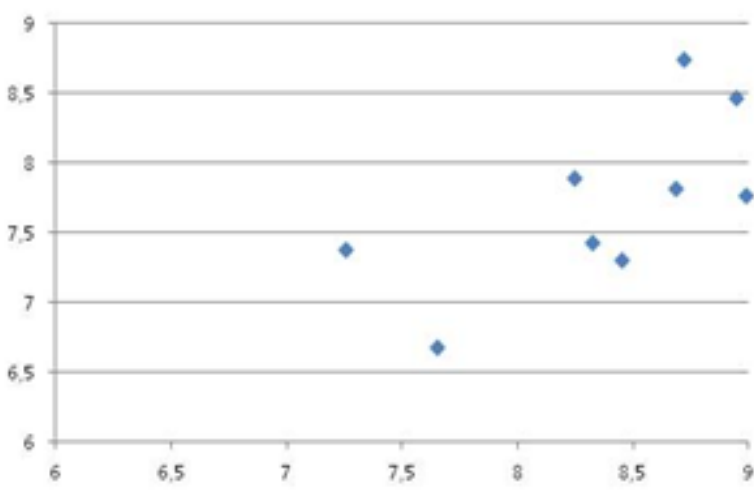

\section{LN (GDP / capita, constant value 2005 USD)}

The countries with the lowest per capita emissions of $\mathrm{CO} 2$ were Paraguay, Colombia and Bolivia, while the largest emitters included Venezuela, Argentina and Chile in terms of CO2:s per capita. The patterns is a different one, although emissions/capita follows GDP/capita. Argentina just as Venezuela certainly has a CO2 problematic, although it does not rank high on total emissions. Taking population size into account changes the picture, but the $40 \%$ reduction goal still obtains whatever emission measue one employs.

\section{Countries}

\section{BRAZIL}

Brazil has for a long time been in the forefront of environmental concerns. On the one hand, it has paved the way for an alternative to the oil dominance in transportation by developing a domestic biomass industry on large scale. The ethanol is derived from immense sugar plantations and it has reduced oil dependency, especially when international petrol prices have skyrocketed. On the other, there is the constant worry that Brazilian governments are ineffective in protecting the lungs of the Planet Earth, the giant rain forest in the Amazon.

First, we may establish that Brazil produces much CO2:s, and this as a function its economic development (Figure 6).

FIGURE 6. GDP-CO 2 in Brazil: $y=1,02 x R^{2}=0,95$ 
GDP - CO2 for Brazil 1990 - 2014

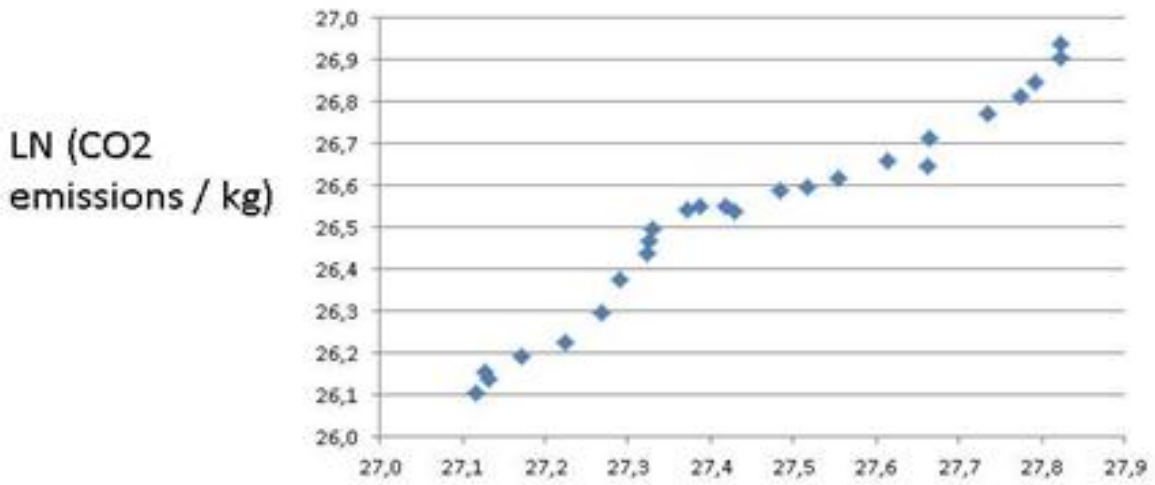

LN (GDP in constant value 2005 USD)

The trend in Brazil for CO2:s is like in Argentina up and up. When the burning of the rain forest is added, then Brazil is one of the largest $\mathrm{CO} 2$ emitter in the world. The country may reply that its energy mix and its huge forests decrease $\mathrm{CO} 2$ :s by consuming carbon (Figure 7).

FIGURE 7. Energy mix of Brazil

\section{Brazil energy consumption 2013}

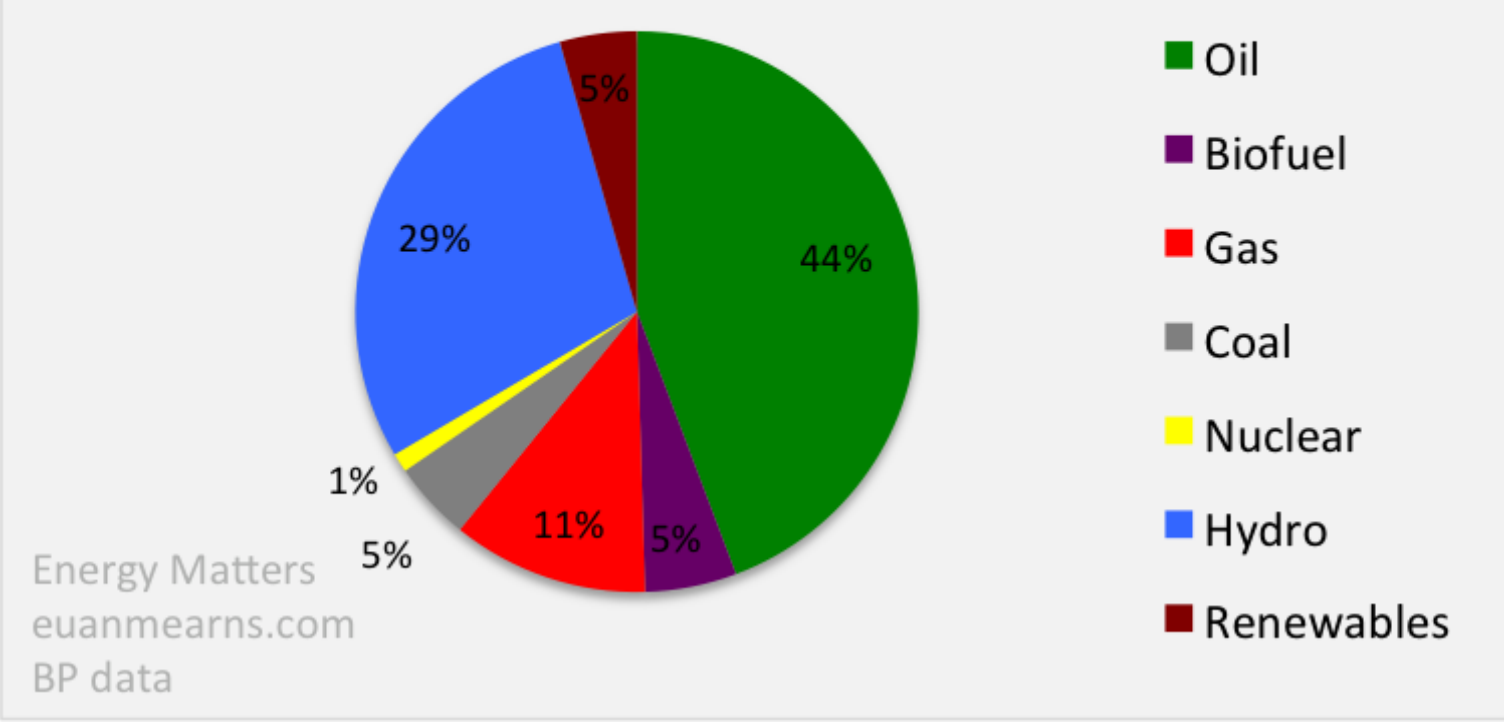

Source: http://euanmearns.com/brazil-samba-energy/

Hydroelectric power is massive in Brazil and capacity has grown steadily since 1965. However, hydro production has been down owing to late and light rains. Brazil is one of the few countries in the world where 
liquid bio-fuel production is significant: ethanol. Gas production in Brazil is significant, but Brazil has very little of coal production. In 2006, the discovery of vast oil resources in the sub-salt strata of the Santos Basin promised petroleum bonanza, but deep water and sub-salt setting has posed technical challenges and high costs. Brazil has 3 nuclear reactors, but nuclear provides merely $1 \%$ of primary energy.

One can hardly say that it will easy for Brazil to live up to its COP21 commitments, despite its comparatively low dependence upon fossil fuels. Its large hydro power supply is vulnerable to draught, as rivers dry up. And then one must add the political difficulties in managing the oil and gas reserves properly in giant enterprise Petrobas. The huge Mato Grosso could be used for renewable energy generation, wind and solar power.

\section{MEXICO}

One would expect to find huge $\mathrm{CO} 2$ emissions in this large emerging economy with lots of oil production. Countries like the Gulf States have massive CO2:s because they drill and refine oil and natural gas. For Mexico holds the following situation (Figure 8).

Figure 8. GDP-CO2 in Mexico: $y=0,77 x ; R^{2}=0,98$

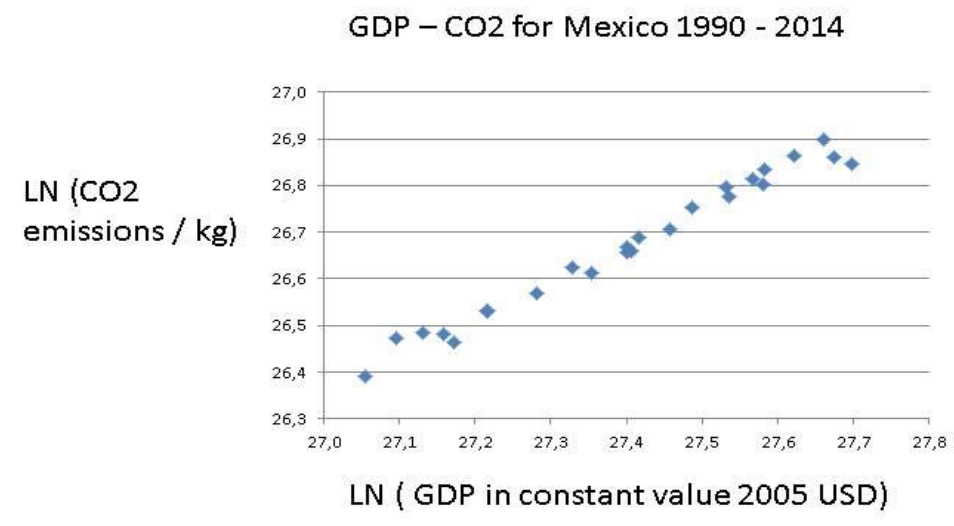

The close link between economic development and $\mathrm{CO} 2$ is to be seen in the data, but the emissions growth seems to stagnate in the last years. This is of course a promising sign, whether it is the start of a COP21 inspired 40\% reduction in CO2:s remains to be seen. I doubt so, but let us inquire into the energy mix of this huge country that is of enormous economic importance to both North and South America (Figure 9)

FIGURE 9. Energy mix for Mexico 


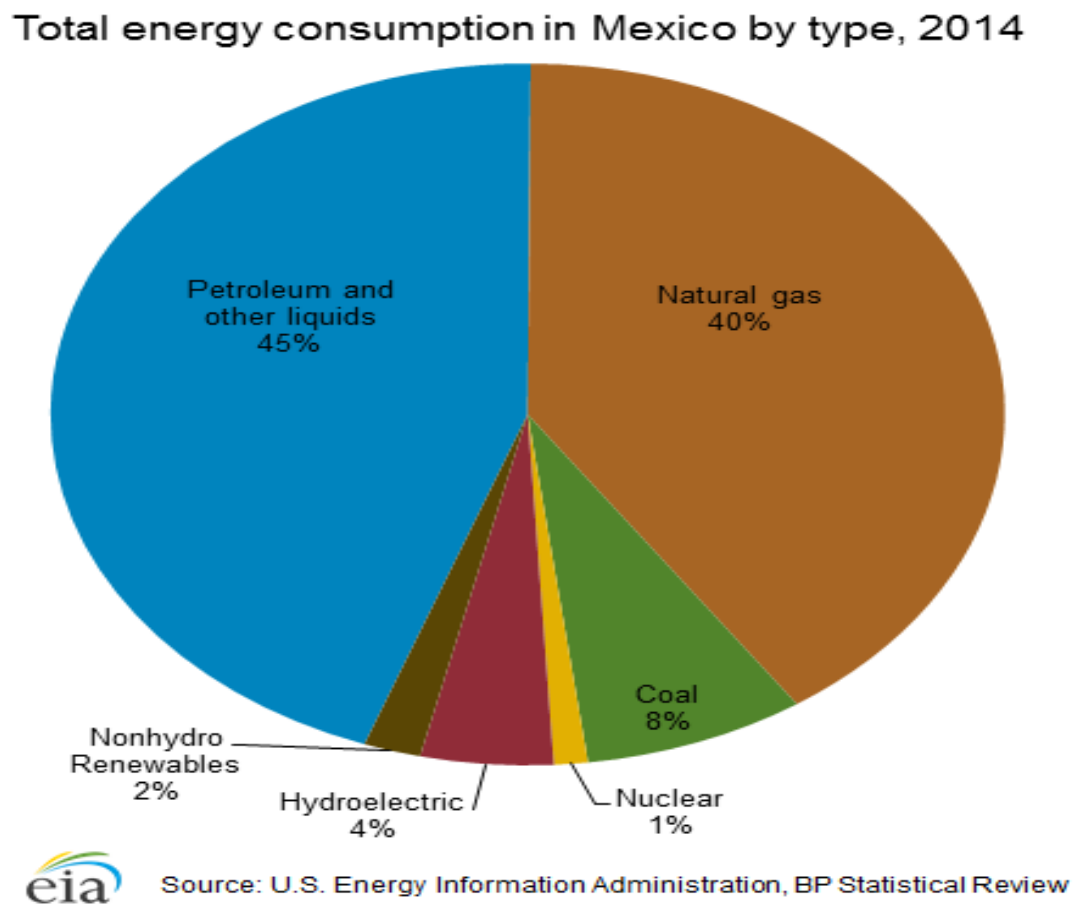

Few countries are so deependent upon fossil fuels as Mexico. One find the same patter with the Gulf States. The Mexican government must start now to reduce this dependency, by for instance eliminating coal and bringing down petreoleum, instead betting upon solar, wind and nuclear power. Mexico will face severe difficulties with the $40 \%$ reduction target in COP21. It has a fast growing population with many in poverty and an expanding industry sucking electricity. Can economic growth and decarbonisation go together here?

\section{VENEZUELA}

Energy is an interesting aspect of this nation, which is now in turmois because of the lack of it, despite the immense oil and gas resources of this country. Just as with otheroil producing countries, one expects the CO2:s to be quite substantial. Figure 10 confirms thiss expectation, but one may note many yearly ups and downs in this Figure. Why this link is not a smooth one may be explained both by the energy mix and the volatile politics of Venezuela.

FIGURE 10. GDP-CO2: $y=0,87 x ; R^{2}=0,85$ 
GDP - CO2 for Venezuela 1990 - 2014

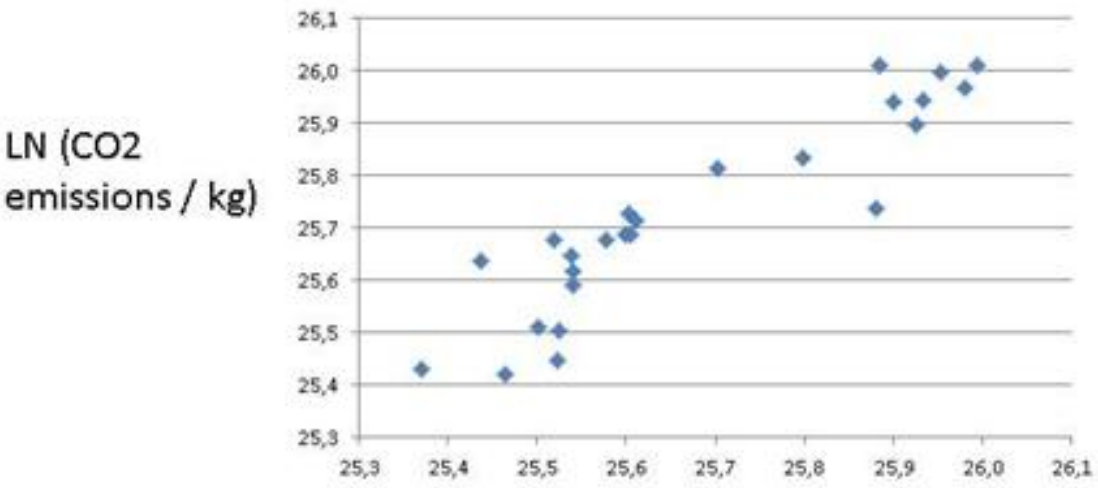

LN (GDP in constant value 2005 USD)

The dependency upon fossil fuels is high in Venezuela, but the country differens from Mexico in that it disposes of considerable hydro power.

\section{FIGURE 11. Venezuela}

\section{Total energy consumption Venezuela, by type (2010)}

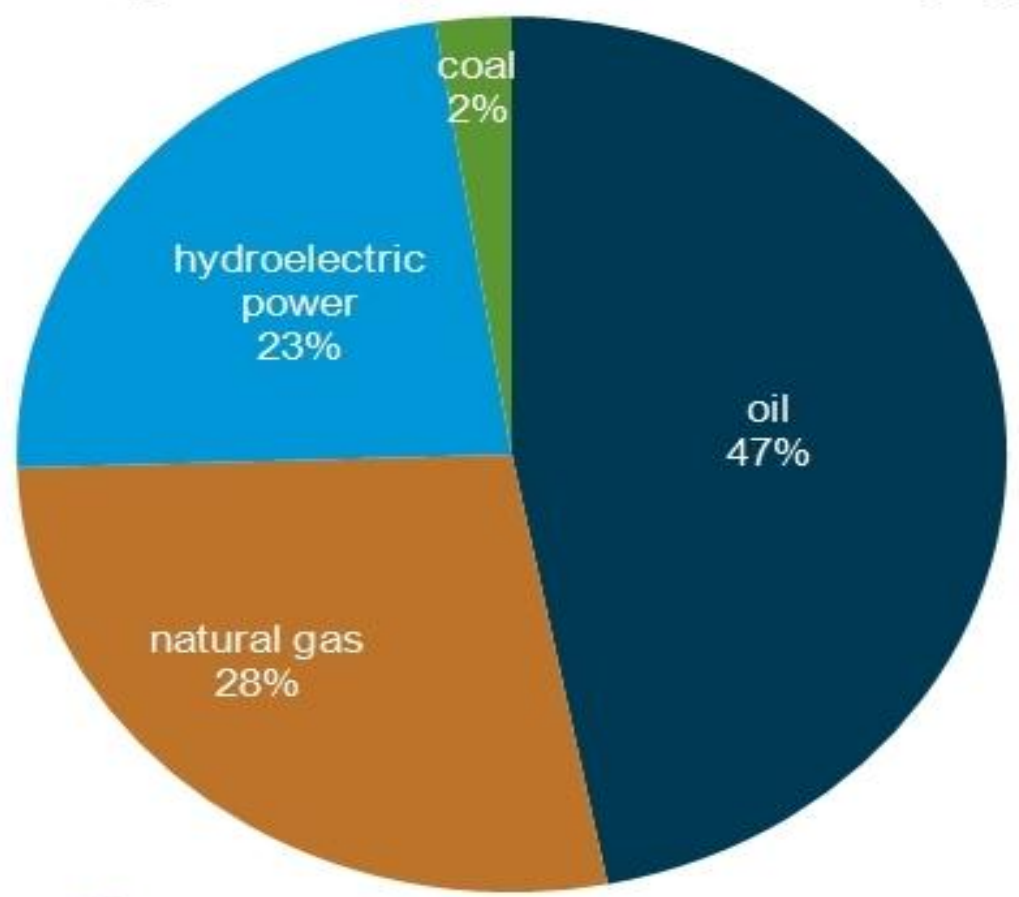

eia Source: U.S. Energy Information Administration

Typical of Latin America is that several countries make use of hydro power to mitigate their dependency upon fossil fuels, mainly oil and natural gas. In the case of Venezuela, it is the water resources that have failed, causing such electricity chaos, resulting in loss of output and work. Strangely, the Venezuelan government has not taken any steps towards precaution, building back up generators based upon its massive oil and gas 
reserves. Perhaps the hope of a totally carbon free society is an illusion: What happens when water dries up for instance?

Summing Up: The exploitation of water power allows Latin American nations to reduce their dependency upon fossil fuels. Yet, global warming may threaten the access to plenty fresh water. Atomic power is used in some of these countries. Solar power could be the future in for instance Mexico, much too reliant upon oil and gas. Brazil uses modern renewables highly but still has much $\mathrm{CO} 2$ emissions. Uruguay and Chile appear to be best positioned for the COP21 implementation process.

\section{(B) AFRICA}

The purpose below is only to map energy related emissions for a few countries in order to get a glimpse at what African governments and societies face when starting to implement the COP21 Agreement. The African continent harbors two kinds of societies or economies. On the one hand there are emerging economies in the North and the South. On the other hand, there are poor countries in the stomach of Africa, many of which have been plagued by political instability and death from domestic violence.

Figure 12 displays the connection between GDP and CO2:s around 1990 for a selection of African nations.

FIGURE 12. GDP-COP $1990\left(\mathrm{y}=1,34 \mathrm{x}, \mathrm{R}^{2}=0,87\right)$

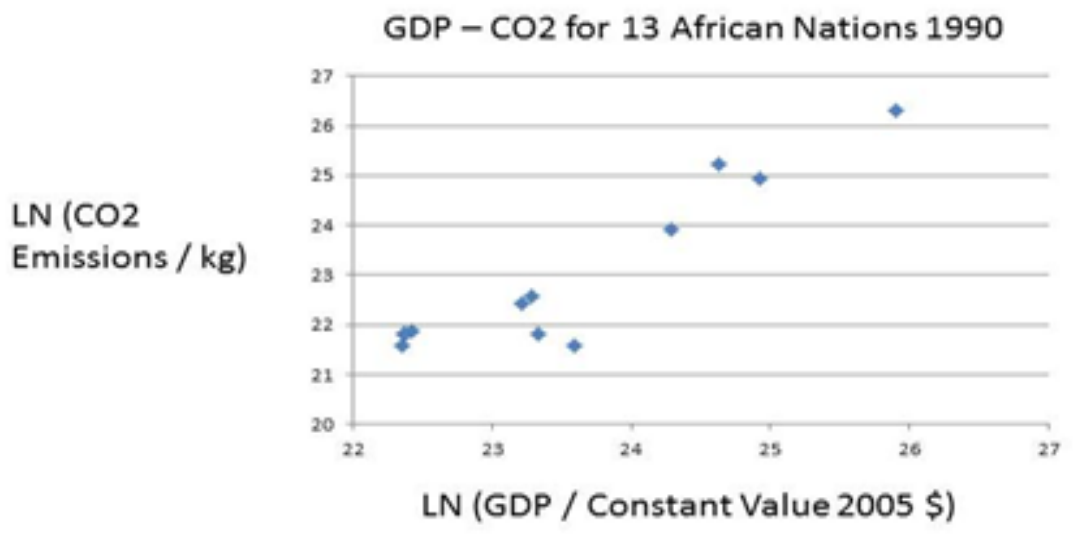

When we look at the same factors in 2014, the link has been strengthened considerably (Figure 13).

FIGURE 13. GDP-CO2 $2014\left(\mathrm{y}=1,47 \mathrm{x}, \mathrm{R}^{2}=0,93\right)$ 
GDP - CO2 for 13 African Nations 2014

LN (CO2

Emissions / kg)

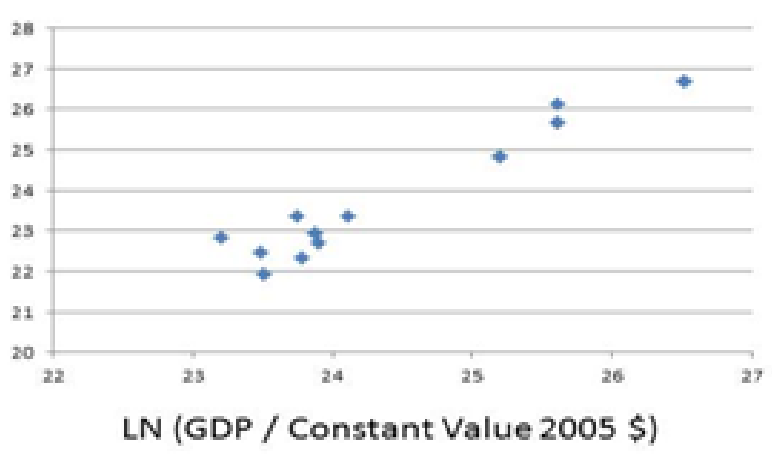

The finding is that African nations face the same problematic as countries on the other continents. They must reduce $\mathrm{CO} 2$ :s while maintaining economic development. What this dilemma entails appears clearly when a few African nations are explored below according to the theoretical framework above.

\section{Countries}

\section{GHANA}

One of the promising nations in Africa is Ghana, housing both democracy and positive economic development. Figure 14 shows its GDP-CO2 picture for the last two decades, when things have gone well and peacefully.

Figure 14. Ghana: GDP-CO2: $y=1,17 x, R^{2}=0,94$

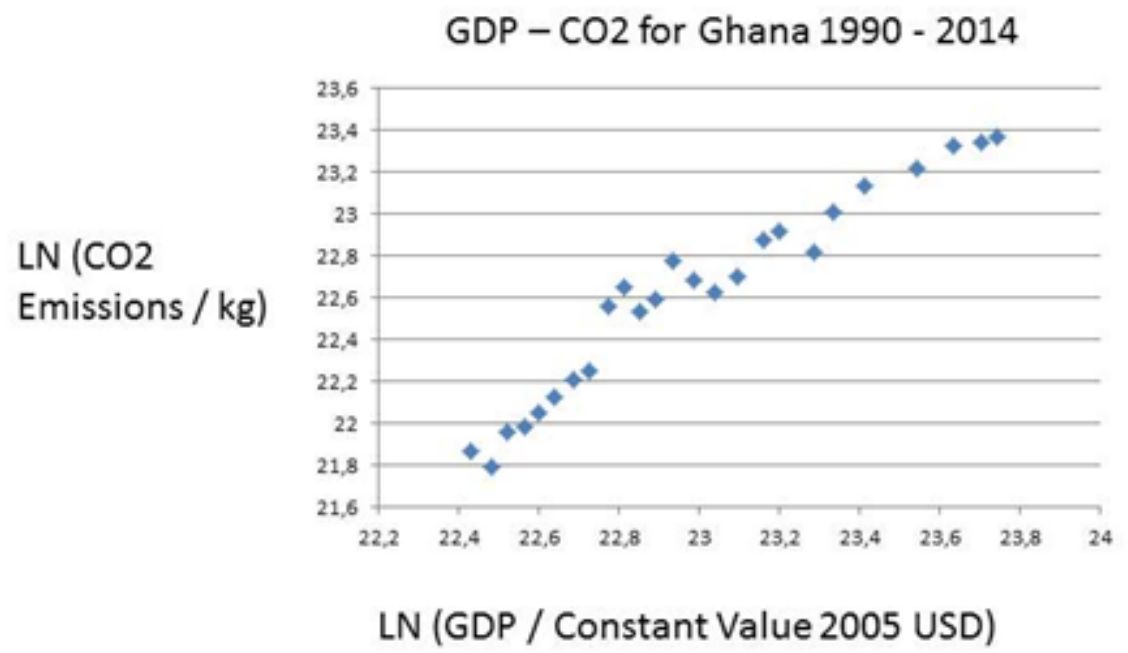

There is a very strong connection between GDP and CO2 emissions in Ghana. One would like to examine its energy mix in order to understand this. Figure 15 present the energy consumption pattern in Ghana.

FIGURE 15. 


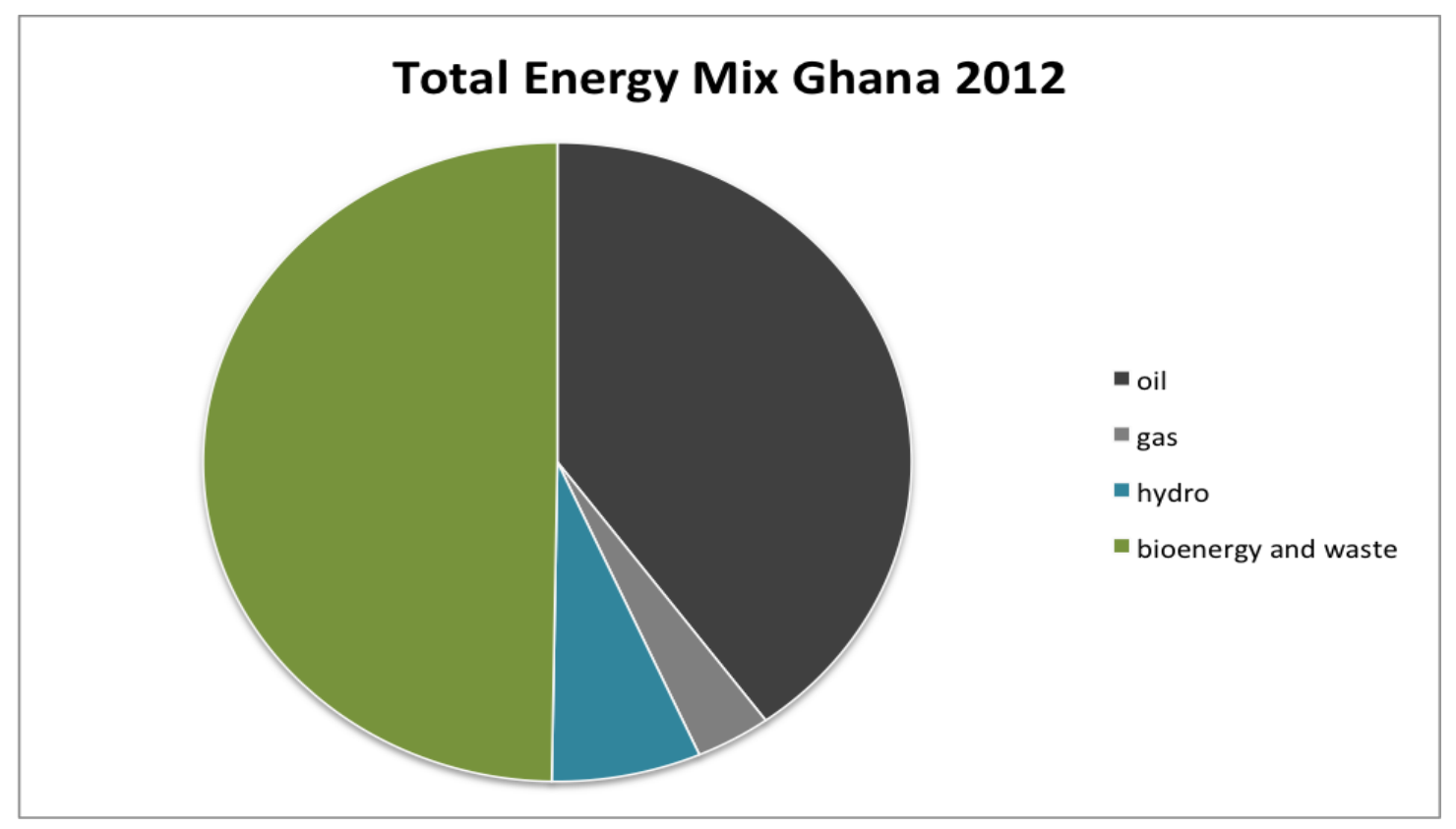

Source: http://climateanswers.info/2015/10/ghana-climate-and-energy-statistics/

Ghana needs both electricity and petrol. Figure 15 shows that oil is used abundantl, but there is also much hydro power. Yet, 50 per cent of the power comes from bioenergy and waste, which is classified as renewables. These kinds of traditional renewables are to be found in almost all sub-saharan Africa countries. And they create large $\mathrm{CO} 2$ emissions, which is why there is this close link between GDP and CO2:s here. Look now at Kenya in Figure 16.

KENYA

FIGURE 16. Kenya: $y=1,08 x, R^{2}=0,95$

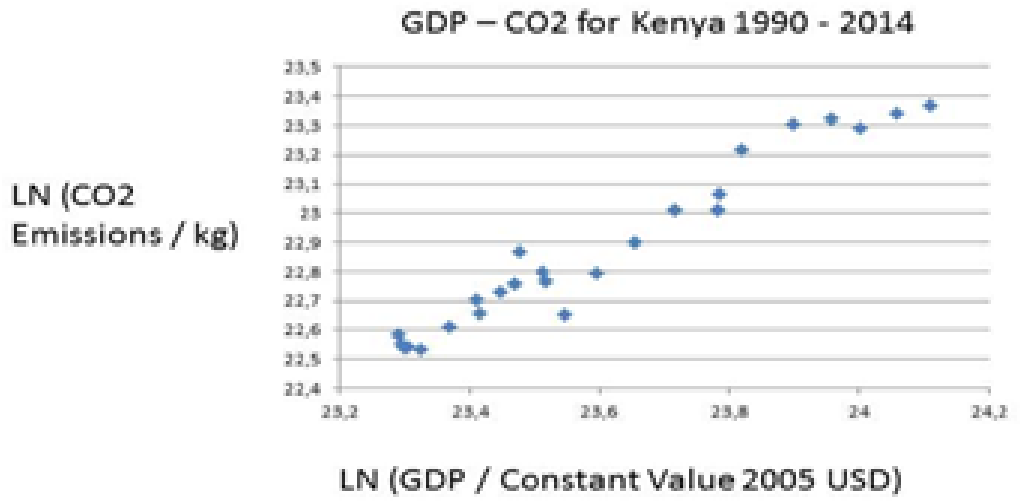

As a matter of fact, Kenya:s curve for GDP and CO2:s resembles that of Ghana, both countries experiencing economic progress. The basic energy resources are also the same: renewables, hydro and petroleum - see Figure 16. 
FIGURE 16. Kenya: enrgy mix

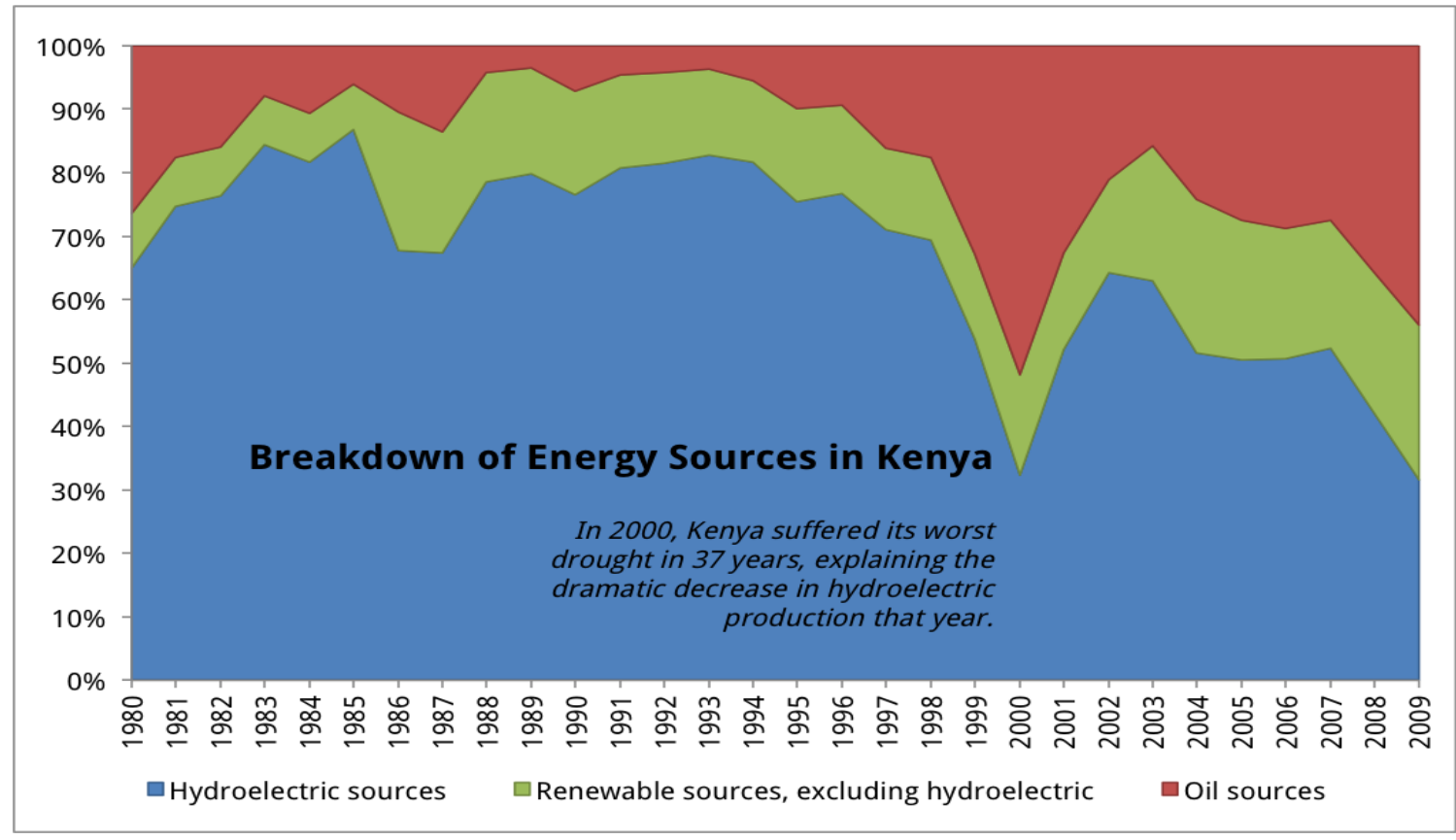

Source: http://investeddevelopment.com/blog/2012/08/energy-in-kenya-and-the 6-potential-for-renewables/

However, these renewables are not all carbon neutral: charcoal and dung, besides the normal renewables like solar, wind and thermal power.

One may expect that countries with the possession of big rivers resort to hydro power, like Senegal, Kongo, Angola and East African states

However, hydro power is nowhere dominant as general energy source. Many poor African nations employ traditional renewables that are far from carbon neutral. An example is the giant Democratic Republic of Congo, where wood and charcoal dominates very much. It is of course a matter of deforestation and desertification when wood and charcoal are used so heavily.

One may speculate as to why hydro power is not more used in several African countries. One reason has already been mentioned, anarchy. Another is of course the enormous investments costs. Hydro power should be more used in countries like Nigeria, Angola and Kongo. But it is not without risks, namely water shortages.

\section{KONGO, DR}

A general tenet in the climate change debate is that renewables should be preferred over non-renewables. Yet, this statement must be strictly modified, as there are two fundamentally different renewables:

- Traditional renewables: wood, charcoal and dung. They are not carbon neutral. On the contrary, employing these renewables results in severe pollution, not only outside but also inside a household;

- New renewables: solar, wind, geo-thermal and wave energy that are indeed carbon neutral, at least at the stage of functioning.

In the poor African countries with about half the population in agriculture and small villages, traditional renewables constitute the major source of energy.

FIGURE 17. DR KONGO 


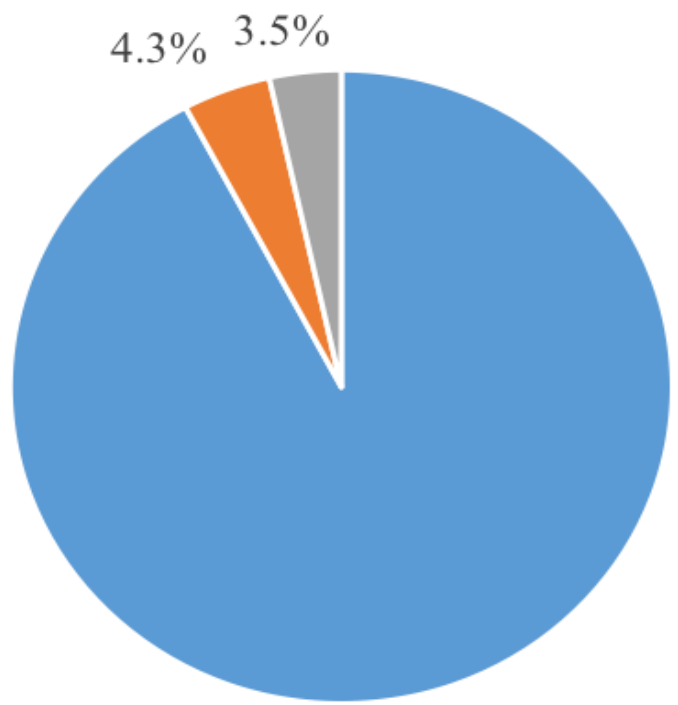

$92.2 \%$

- Biofuels \& waste " Oil " Hydro

Source: Democratic Republic of Congo - Energy Outlook, Kungliga Tekniska Hogskolan

One notes how little of hydro power has been turned into electricity in Kongo, but economic development and political instability, civil war and anarchy do not go together normally. At the same, one may argue that an extensive build-up of hydro power stations would pose a severe challenge to the fragile environment in the centre of Africa. Kongo can now move directly to modern renewables like solar power.

When we turn to the already industralised countries in North and South Africa, the energy patterns is entirely different from above. As many African countries have reached their "take-off" stage, they need energy, especially electricity. Yet, the African scene is highly diverse, with on the one hand economic success stories and on the other hand the spread of anarchy and lawlessness. For the environment on the African continent, both energy exploitation and criminals', rebels' or terrorists' activities are negative events all the time, resulting in poaching and loss of animal habitat. Let us look at the emissions-energy situation in a few countries that are stable: Egypt, Algeria and South Africa.

\section{ANGOLA}

This enormous reliance upon traditional renewables is to be found also in Angola and Nigeria, although both have access to both hydro power and fossil fuels. Figure 18 describes the energy mix for Angola.

\section{FIGURE 18.}




\section{Figure 1. Angola's primary energy consumption, 2012}

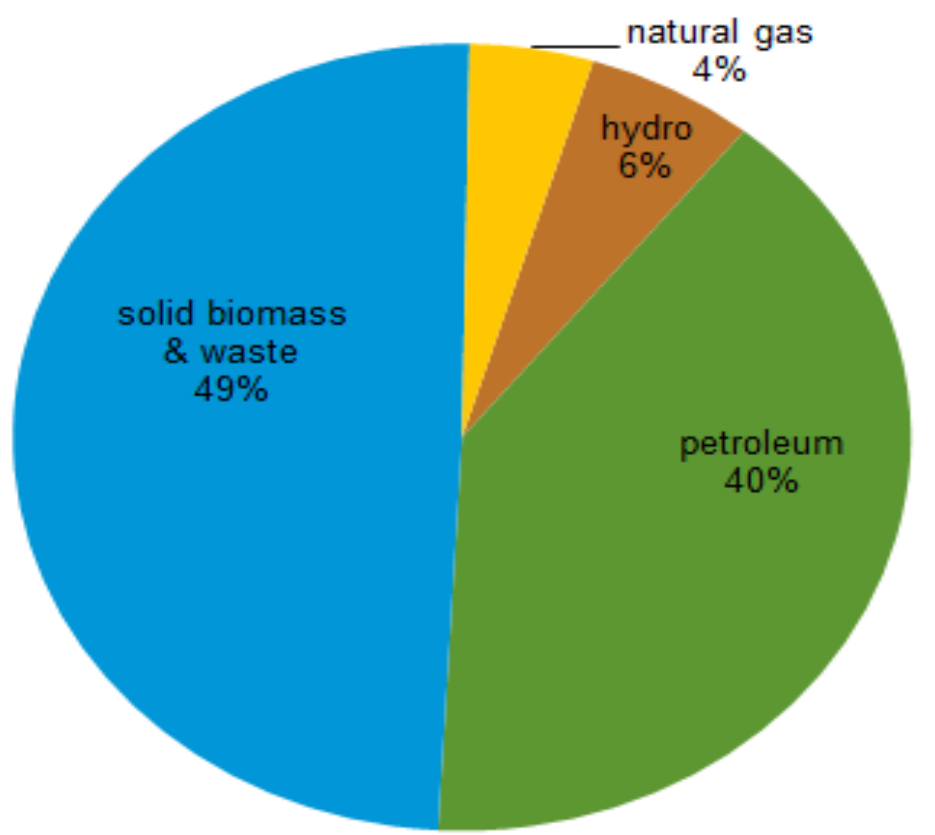

eia Source: U.S. Energy Information Administration and International Energy Agency

Angola like Kongo has suffered from long and terrible civil war. In the mass of poor villages, energy comes from wood, charcoal and dung - all with negative environmental consequences. Angola has immense fossil fuels - oil and gas, but the political elite family may prefer to export these resources instead of using them for electricity generation

\section{EGYPT}

Egypt has a huge population with high unemployment and mass poverty besides a certain level of political instability, resulting from religious conflicts. But surely it has electricity from inta giant Assuam dam and the Nile? No, it does not coult for much where most people live in the Nile delta (Figure 19).

FIGURE 19. 


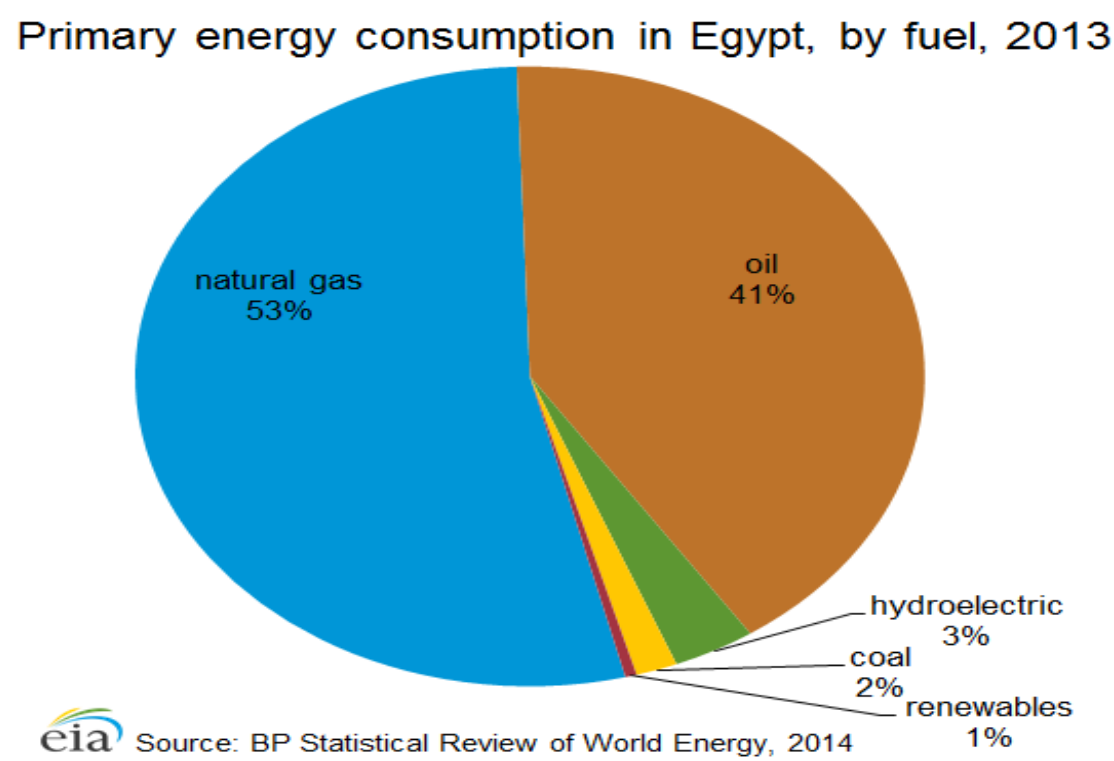

The share of hydro power is stunning low for a country with one of largets rivers in the world. Actuallu, the water of the Nile is the source of interstate confrontation between Egypt, Sudan and Ethiopia.

As Egypt relies upon fossil fuels, it has massive $\mathrm{CO} 2$ emissions, the trend of which follows its GDP (Figure 20).

FIGURE 20. GDP-CO2 for Egypt: $y=1,02 x ; R^{2}=0,99$

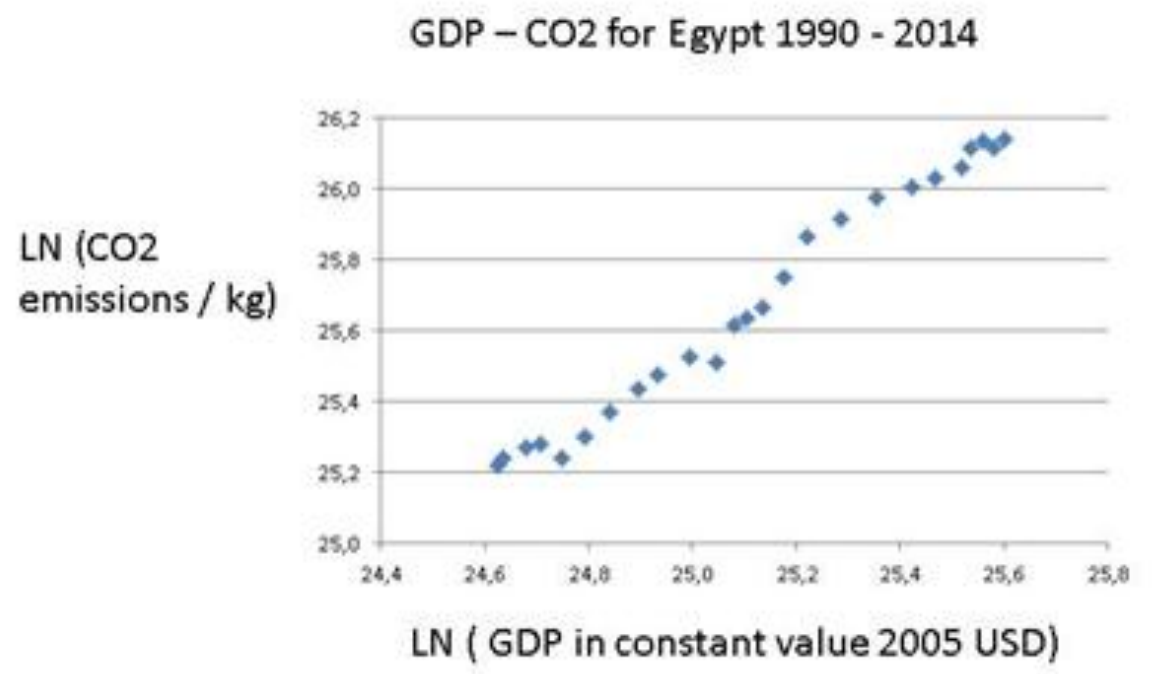

It will be very difficult for Egypt to make the COP21 transformation, at least without massive external support. But where to build huge solar power plants in a country with terrorism, threat or actual?

\section{ALGERIA}


Algeria is a major exporter of natural gas and oil, Thus, we expect that it relies mainly on fossil fuels, like Mexico and the Gulf States. Figure 21 verifies this expectation.

FIGURE 21.

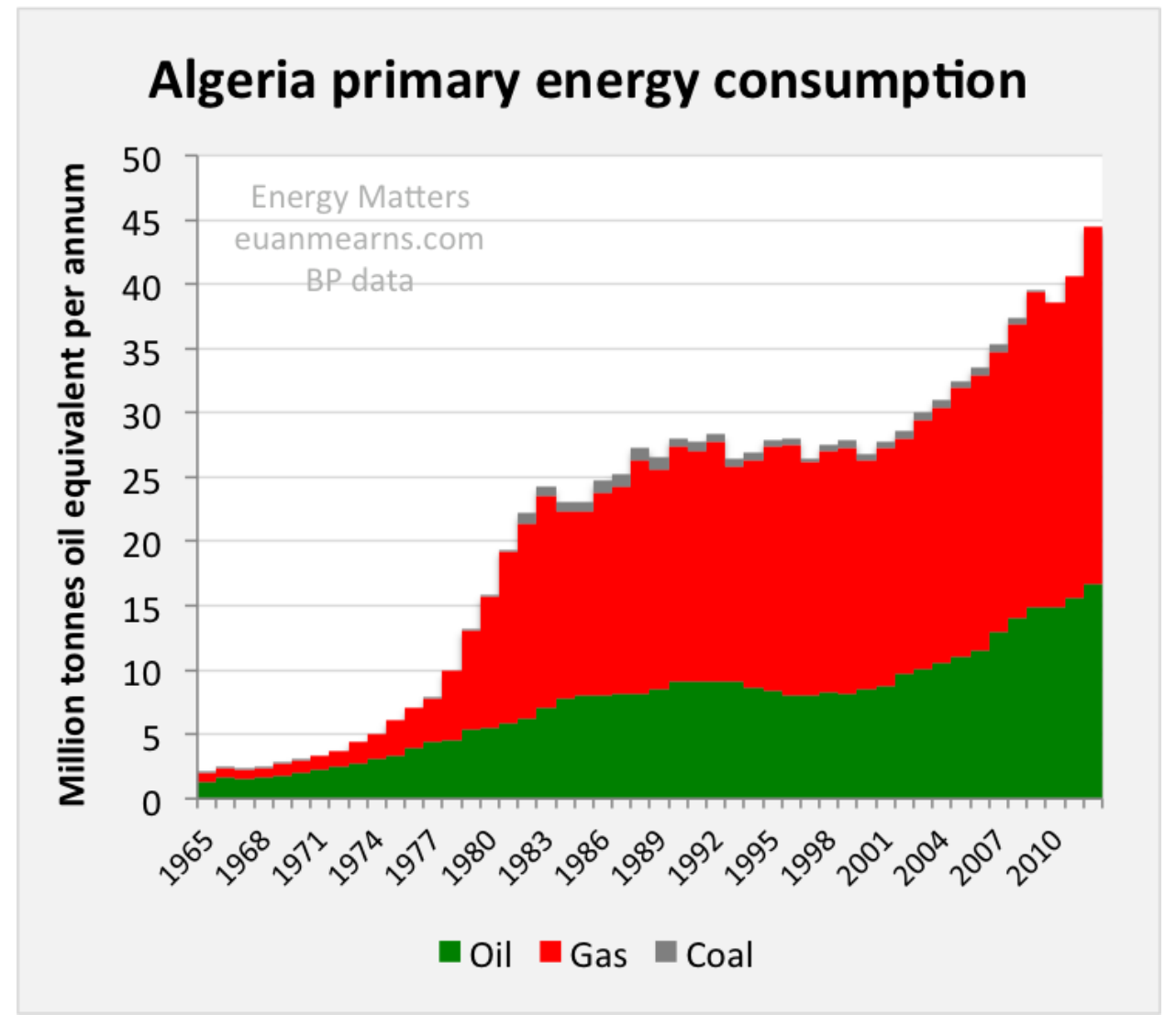

Source: http://euanmearns.com/post-peak-algeria/

Although Algeria may trust in the availability of future fossil fuels resources, it still faces the demand for a $40 \%$ reduction of its $\mathrm{CO} 2$ emissions. They have thus farfollowed the economic progress option or preference.

One would naturally suggest solar energy as a viable alternative to the heavy dependence upon fossil fuels in Algeria, given its immense Saharan territory. Yet, also Algeria has been plagued by the attacks of terrorists or looters.

The COP21 framework outlines the three main goals for the 21rst century in order to keep Planet Earth habitable. Thus, these 3 objectives are now accepted as desirable, but scholars now question whether they are feasible, at least without massive costs or economic decline and global depression (Sachs, 2015). A few countries are almost completely dependent upon coal. How will they implement the COP21 goals? Look at South Africa. Emissions are high, because South Africa uses a lot of coal to generate electricity. Decarbonisation will be difficult and costly. The reliance upon coal in this largest economy in Africa is stunning. 
The RSA has a modern economy running on mainly coal (Figure 22). In transportation, it uses petroleum. This makes the RSA a major polluting nation. It wants to spread electricity to all shanti-towns, but with what energy source?

FIGURE 22. Energy consumption in RSA

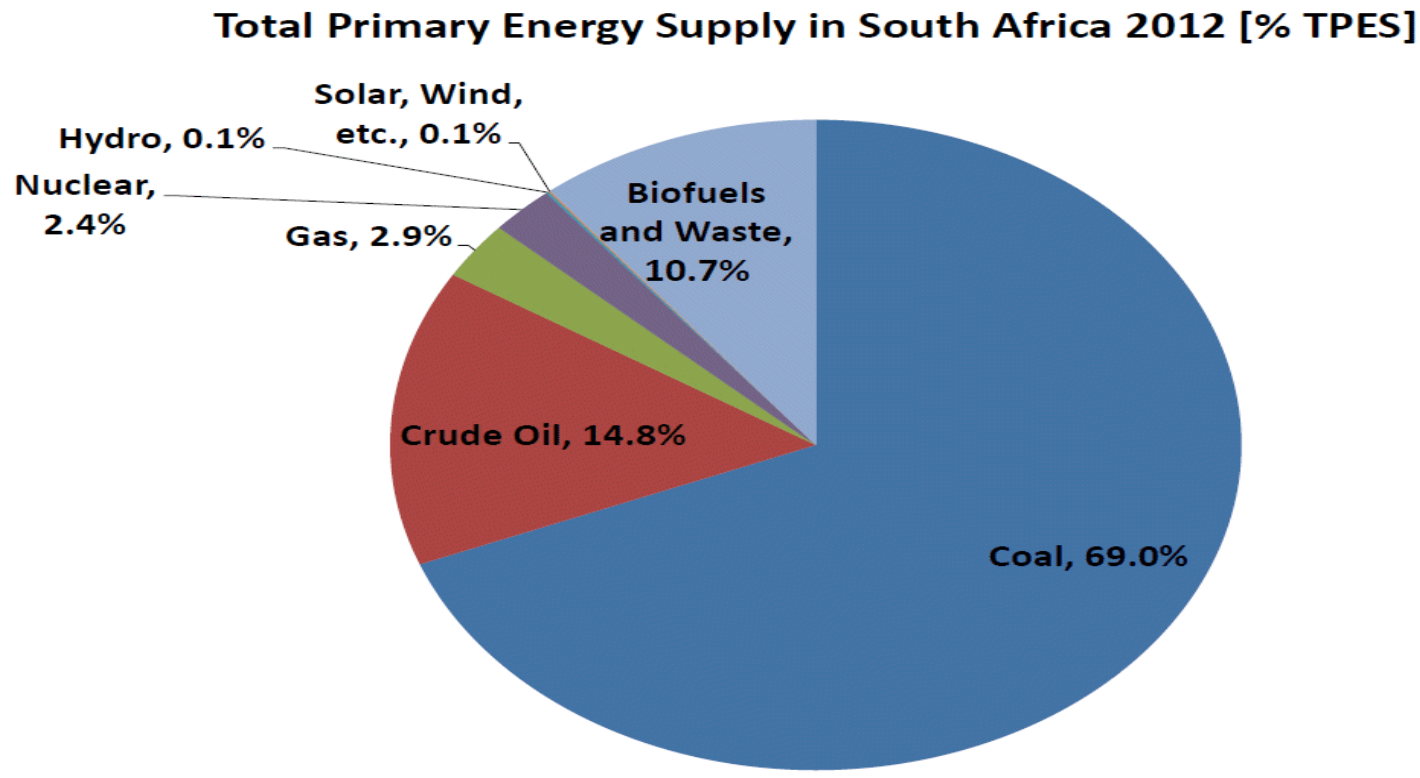

Does the RSA have the resources and motivation to cut the coal consumption radically and move to solar energy for instance? Or could the RSA renege - the always available option in collective action endeavours.

Summing Up: The African continent is so heavily dependent upon solids that implementing the COP21 objectives will prove exceedingly problematic, especially without support from the Super Fund. Some nations rely almost exclusively upon oil and gas or coal, whereas others depend upon wood, charcoal and dung. Hydro power is exploited, but will water suffice for instance in the Nile Delta that several countries share? Atomic power is completely lacking. The solar power plant is the only way out in order to reduce solids and oil and gas.

\section{(C) ASIA}

Climate change is extremely complex as a set of phenomena and a model of it needs to simplify in order to emphasize a few essential features. Here, I select the GDP, energy consumption and GHG emissions, especially the $\mathrm{CO} 2$ emissions. According to this model simplification, GDP requires enormous amounts of energy consumption in a wide sense that results in the emission of GHG:s, mainly about 70 per cent CO2:s. This model bypasses other sources of $\mathrm{CO} 2$ :s from natural causes and concentrates only upon the so-called anthropogenic ones, as with COP21. One may of course look at the $\mathrm{C} 2$ from an overall biological perspective, analysing the incredible amounts that cycle all the time. The anthropogenic contribution of $\mathrm{CO} 2$ emissions is tiny in comparison, but according to the COP21 approach decisive for clime change.

How, then about CP2 emissions in Asian countries from human activities, mainly of en economic import? Start with Figure 23. 
Figure 23. The 1990 Situation: GDP and CO2 in Asian Countries $\left(y=0,60 x, R^{2}=0,5\right)$

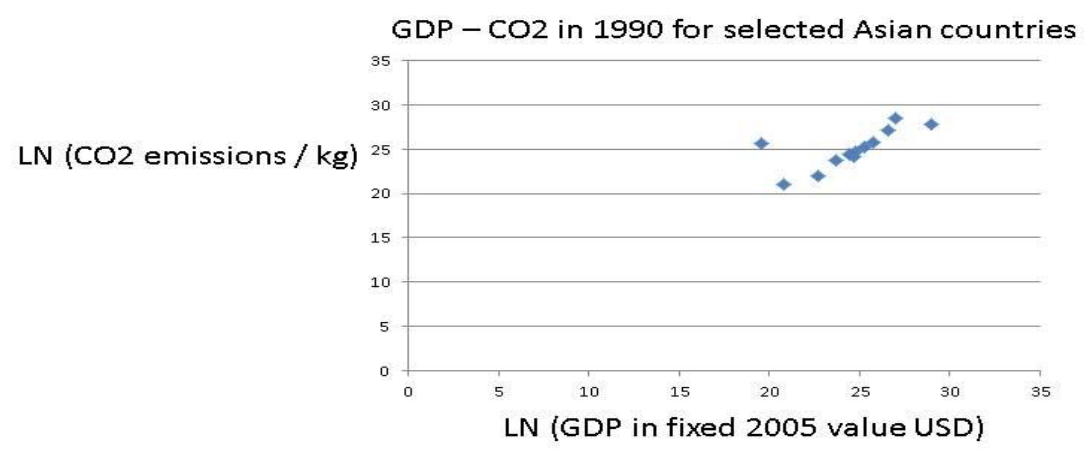

The link between total CO2 emissions and overall GDP is to be found in the early 1990s for Asia, as the richer countries pollute more than the poorer ones. Yet, the connection is not very strong. Figure 24 shows how things developed during the two decades of mainly quick economic development and the spread of the Asian economic miracle from the 4 tigers to almost all Asian countries, especially the giants, viz China, India and Indonesia.

Figure 24. The 2014 Situation: GDP and CO2 in Asian Countries $\left(y=1,02 x, R^{2}=0,91\right)$ 


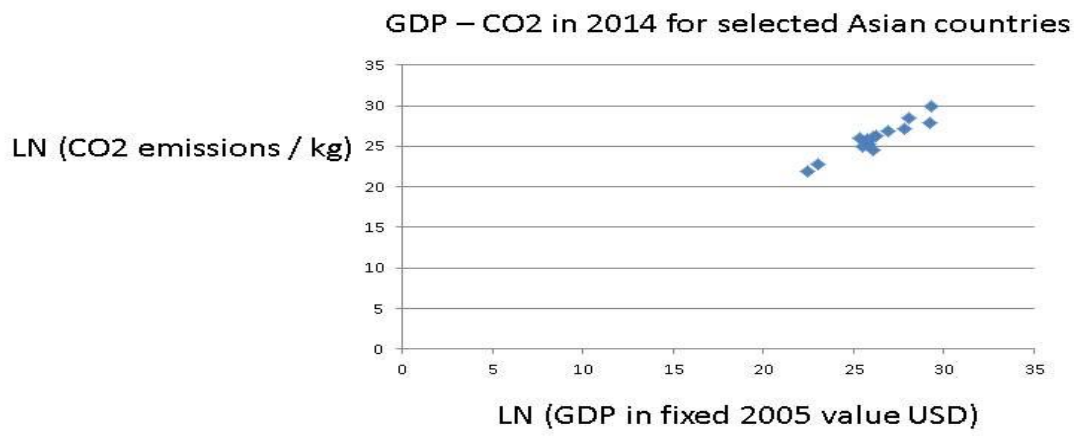

Today, the $\mathrm{CO} 2$ emissions are much larger for all Asian countries, following the increase in economic output, or GDP closely. These enormous emissions of $\mathrm{CO} 2$ put the Asian region in the top most polluted regions in the world, besides North America and The EU. The consequences are visible in the huge cities in Asia, where smog levels have skyrocketed, hurting the health of ordinary people, like in Delhi, Beijing and Bangkok, etc.

It has often been pointed out that practical environmentalism would be much in the self-interest of Asian peoples, but the reasons of environmental degradation in this region is not a lack of theoretical environmentalism in the minds of people but the clash between ecology and economic development or growth. The immense increase in both GDP per capita and emissions per capita in Figures 23 and 24 would have been impossible without the massive use of energy, i.e. fossil fuels.

\section{Countries}

\section{China}

One finds that the emissions of $\mathrm{CO} 2$ :s follows economic development closely in many countries, like China, South Koreas and most Latin American countries. The basic explanation is population growth and GDP growth - more people breathing and searching for higher life style. Take the case of China, whose emissions are the largest in the world, totally speaking (Figure 25). Interestingly, China has begun a fundamental change of its energy policy in 2015 , reacting to mostly domestic demands for cleaner air and environment.

FIGURE 25. CHINA: LN (CO2/ Kg and LN (GDP / Constant Value 2005 USD) $\left(y=0,7 x ; R^{2}=0,97\right)$ 


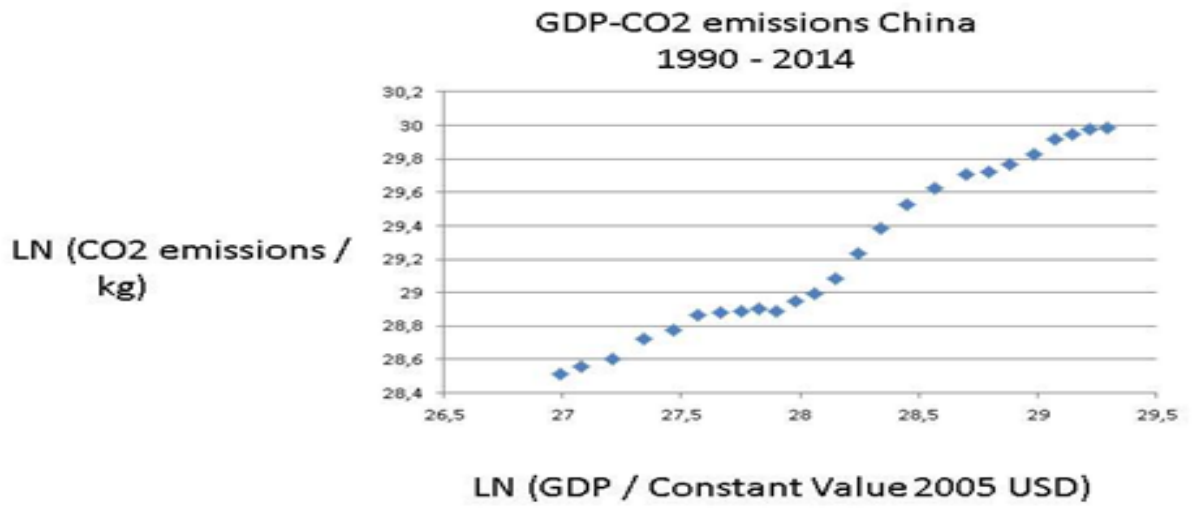

The sharp increase in $\mathrm{CO} 2$ :s in China reflects not only the immensely rapid industrialization and urbanization of the last 30 years, but also its problematic energy mix (Figure 26), which is now up for overhaul.

FIGURE 28.

\section{China energy consumption 2014}

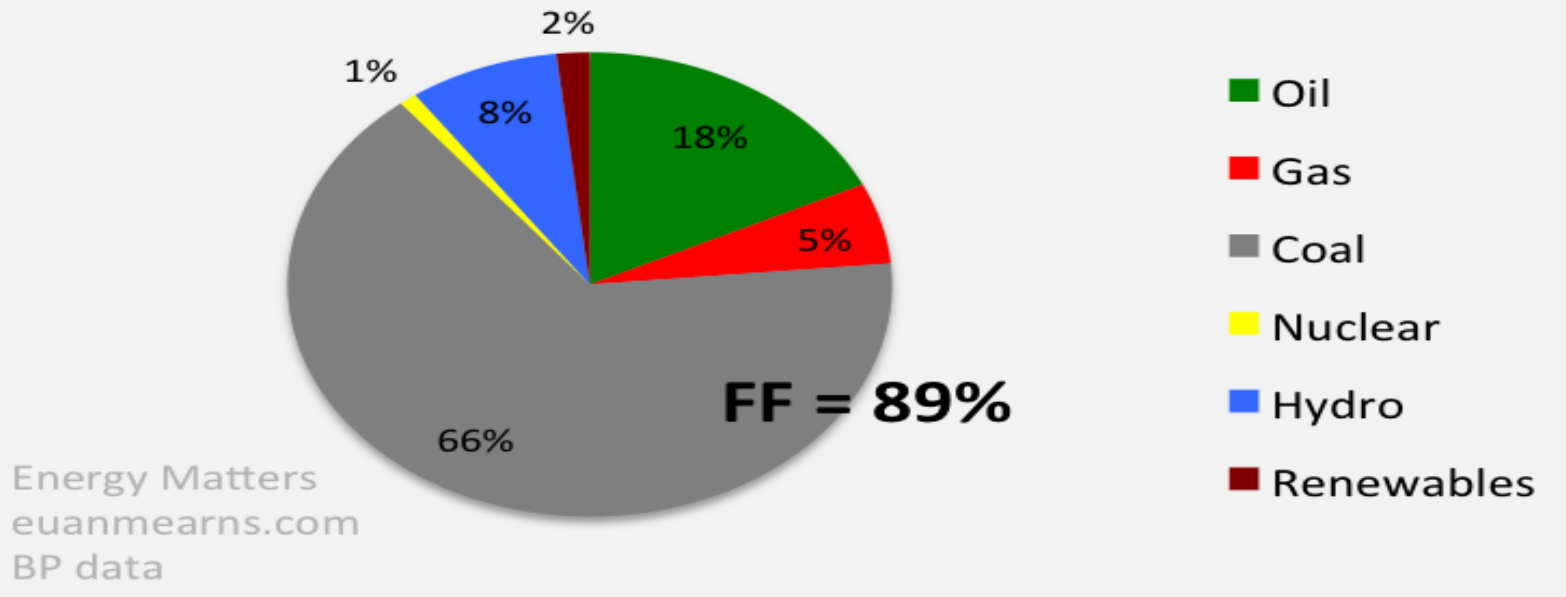

Source: http://euanmearns.com/china-post-industrial-revolution

Almost 70 per cent of the energy consumption comes from the burning of coal with an additional 20 per cent from other fossil fuels. The role of nuclear and renewable energy sources except hydro power is very small indeed. This energy mix makes China very vulnerable to demands for radically cutting CO2 emissions: use other energy sources or massive installation of highly improved filters for carbon capture? It is true that China has turned to wind power, solar power and nuclear power massively recently, but the task of achieving a $40 \%$ 
reduction is enormous. China evidently hopes to respect its COP21 commitments while still enjoying an economic growth rate of above 5\%, but it is realistic? New coal plants have actually been opened recently, replacing out-dated old ones in order to propel growth.

It should be pointed out that several small countries have much higher emissions per capita than China. This raises the enormously difficult problematic of fair cuts of emissions. Should the largest polluters per capita like the rich Gulf States cut most or the biggest aggregate polluters, like emerging economies China, India and Indonesia for instance? At COP21 this issue about redistribution was resolved by the creation of a Super Fund to assist energy transition and environment protection in developing counties, as proposed early by economist Stern (2007)

\section{India}

India is even more negative than China to cut $\mathrm{CO} 2$ emissions, as it is in an earlier stage of industrialization and urbanization. Figure 27 shows the close connection between emissions and GDP for this giant nation.

FIGURE 27. INDIA: LN (CO2/ Kg and LN (GDP / Constant Value 2005 USD)

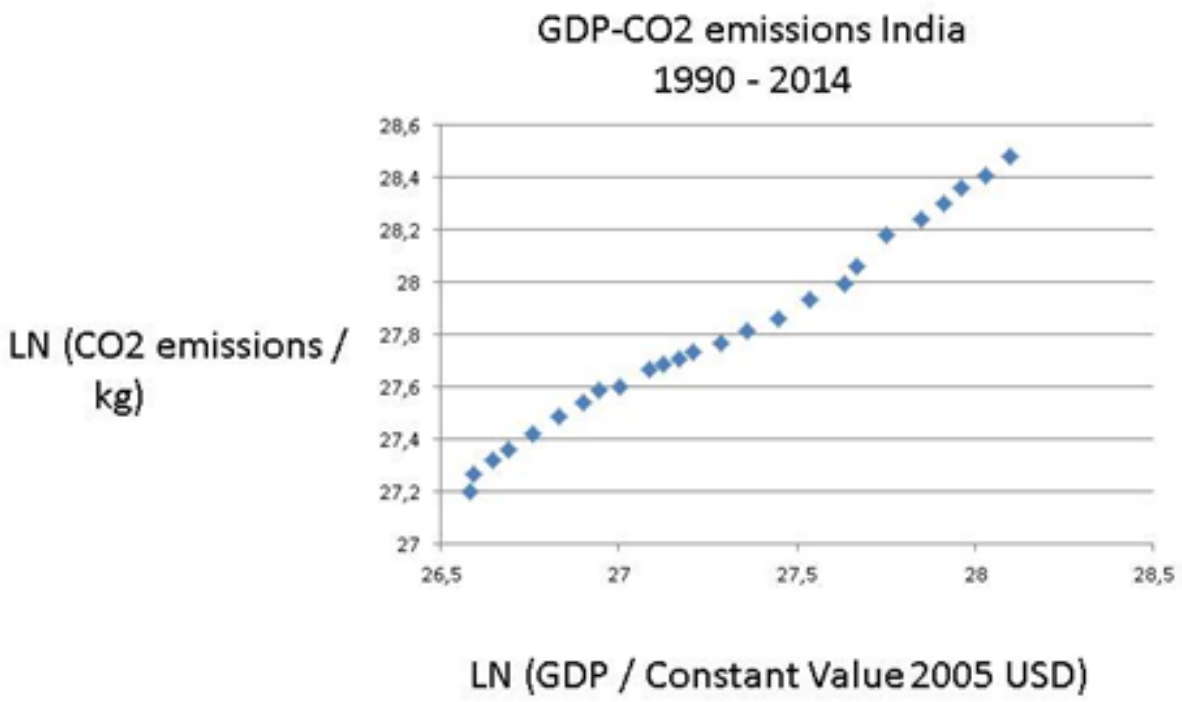

India needs cheap energy for its industries, transportation and heating as well as air-conditioning, meaning it aims strongly at electrification. From where will this power come? India has water power and nuclear energy, but relies most upon coal, oil and gas as power source. It has strong ambitions for the future expansion of energy, but how is it to be generated, the world asks. India actually has a most small number for energy per capita, although it produces much energy totally. Figure 28 shows its energy mix where renewables play a bigger role than in China. However, the renewables in India may lead to deforestation and considerable pollution.

\section{FIGURE 28.}


Figure $1.4 \triangleright$ Primary energy demand in India by fuel
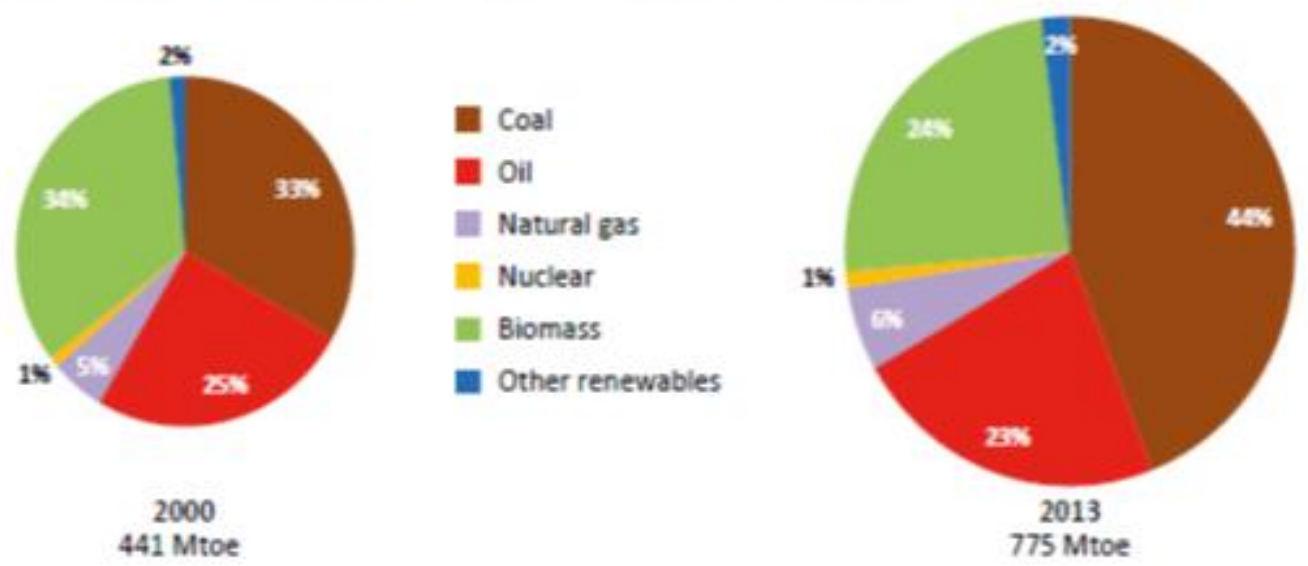

Source: http://www.eia.gov/beta/international/analysis.cfm?iso=IND

India needs especially electricity, as 300 million inhabitants lack access to it. The country is heavily dependent upon fossil fuels (70 per cent), although to a much less extent than China. Electricity can be generated by hydro power and nuclear power, both of which India employs. Yet, global warming reduces the capacity of hydro power - water shortages - and nuclear power meets with political resistance. Interestingly, India uses much biomass and waste for electricity production, which does not always reduce $\mathrm{CO} 2$ emissions. India's energy policy will be closely watched by other governments and NGO:s after 2018. The constant tension between the demand for economic growth on the one hand and environmental protection on the other hand is sharply portrayed in Ramesh (2015).

The same upward trend holds for another poor developing country with huge population, namely Pakistan (Figure 29). 


\section{Pakistan}

FIGURE 30. PAKISTAN: LN (CO2 / Kg and LN (GDP / Constant Value 2005 USD) $\left(\mathrm{y}=1,05 \mathrm{x}-0,97 ; \mathrm{R}^{2}=\right.$ $0,96)$

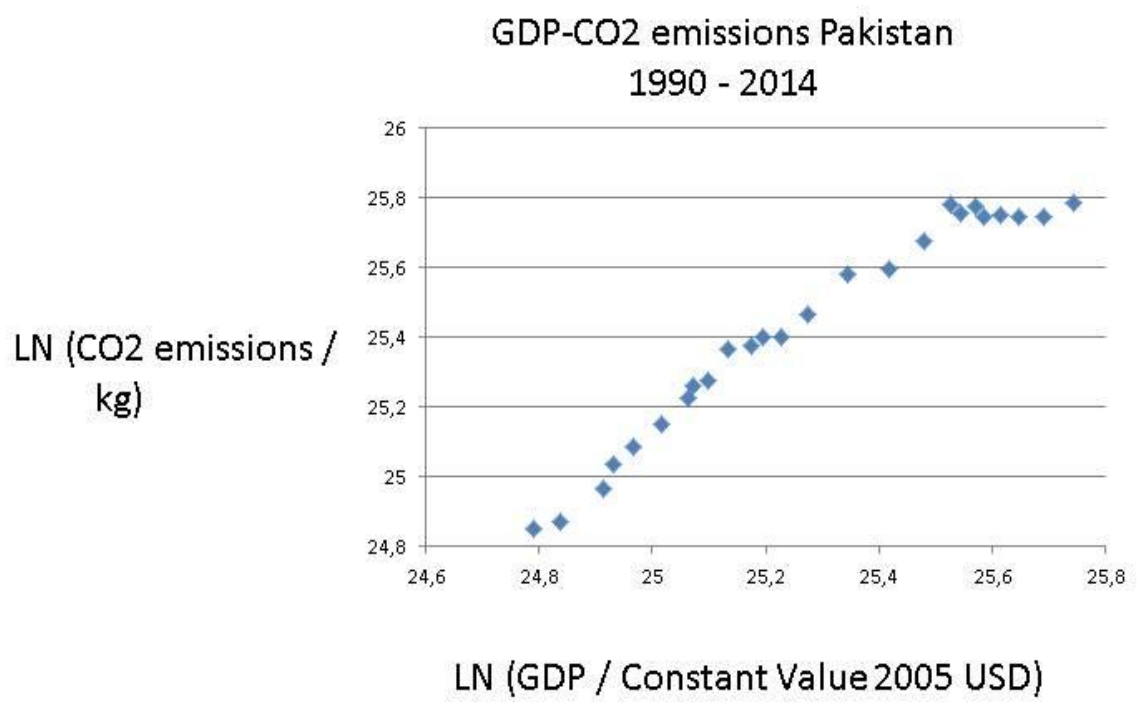

he amount of $\mathrm{CO} 2$ emissions is high for Pakistan, viewed as aggregate. Pakistan is mainly reliant upon fossil fuels, but not coal among them (Figure 30). Actually, it has a rather mixed bag of energy sources.

FIGURE 32. Pakistan Energy Consumption 2009 (by ShoXee: http://i27.tinypic.com/2h6cyag.jpg)

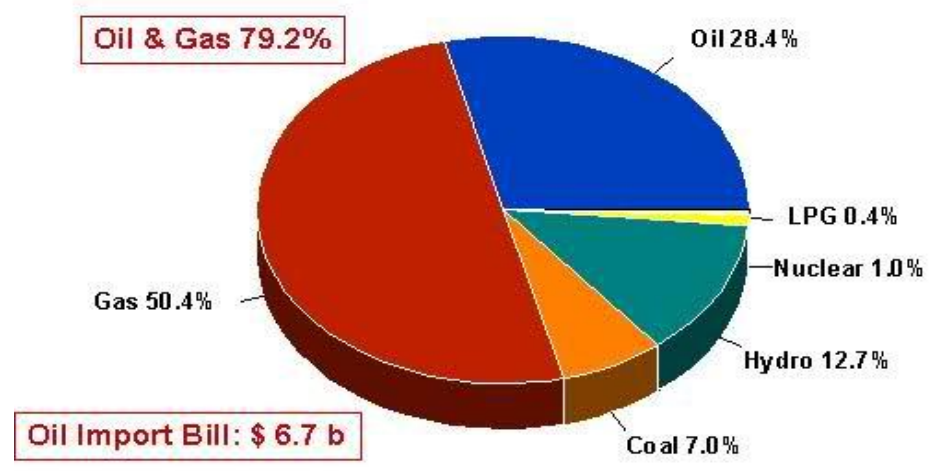


But Pakistan employs a considerable portion of hydropower - 13 per cent - and a minor portion of nuclear power. Can it further develop nuclear and hydro power, or start using solar power on a large scale,

One may guess correctly that countries that try hard to "catch-up" will have increasing emissions. This was true of China and South East Asian countries. Let us look at three more examples, like e.g. giant Indonesia now the fourth largest emitter of CO2:s in the world (Figure 31).

\section{Indonesia}

The growth-emission path appears in Figure 31.

Figure 31. INDONESIA: LN (CO2 / Kg and LN (GDP / Constant Value 2005 USD)

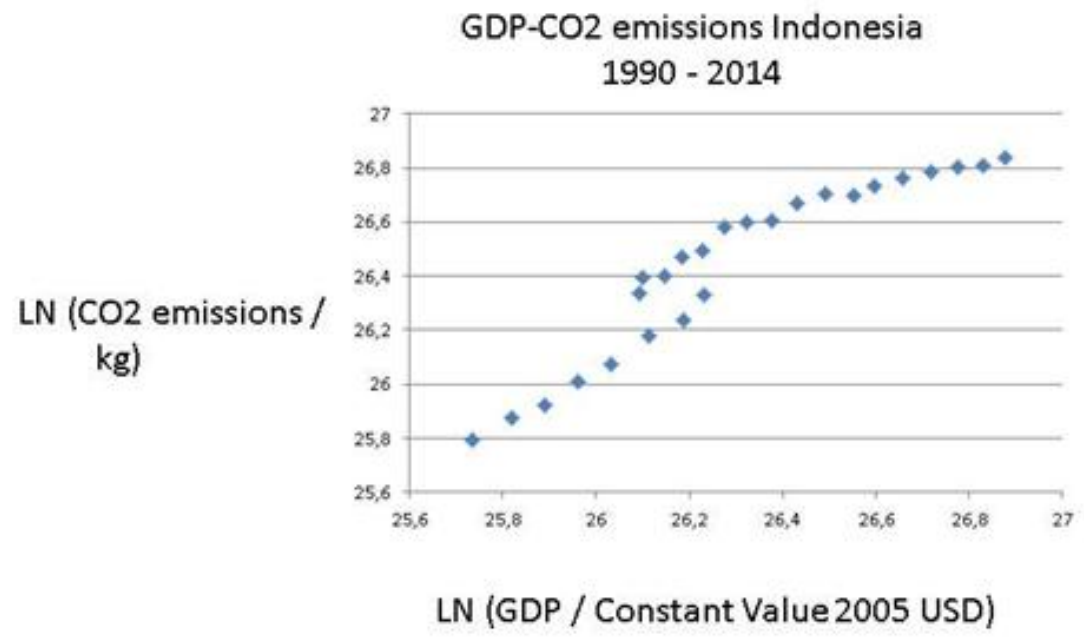

Indonesia is a coming giant, both economically and sadly in terms of pollution. Figure 31 reminds of the general upward trend for East Asia. However, matters are even worse for Indonesia, as the burning of the rain forests on Kalimantan and Sumatra augments the $\mathrm{CO} 2$ emissions very much. Figure 32 presents the energy mix for this huge country in terms of population and territory.

FIGURE 32. INDONESIA: Energy mix

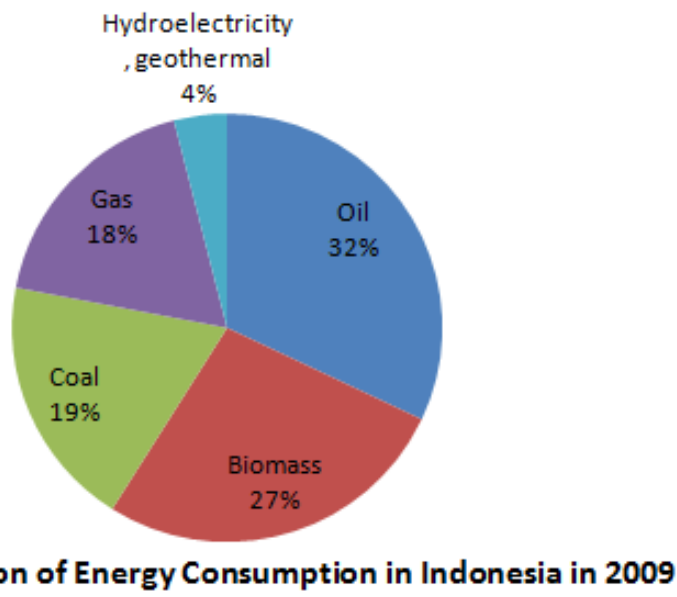


Source: (http://missrifka.com/energy-issue/recent-energy-status-in-indonesia.html)

Only 4 per cent comes from hydro power with 70 per cent from fossil fuels and the remaining 27 per cent from biomass, which alas also pollutes. One can be sure that it is mostly a question of tradition renewables - wood, charcoal - and they pollute a lot.

Summing Up: South Asia, East Asia and South East Asia play a most critical role in the COP21 implementation process. They are responsible for almost 50 per cent of the $\mathrm{CO} 2$ emissions. And they plan to increase their energy consumption enormously in the next decades. They hope for carbon neutral energy sources, replacing solids and fossil fuels like oil and gas, turning to solar and atomic power. The investment needs are simply immense and quite unrealistic

\section{CONCLUSIONS}

The COP21 objectives of decarbonisation must now be a major challenge for the Third World: How to substitute solids and fossil fuel energy with moderns renewables without loosing the capacity to proceed with economic development and poverty reduction? Perhaps coping with global warming and control the COP21 implementation process to some extent is the greatest challenge in this century, for Asia as well as for other regions on the globe?!

With COP21, energy and emissions policy-making now becomes a question for international governance. It is supposed to go on for decades, involving country evaluation and soft control. Yet, the COP21 approach is a decentralised one, combined with international oversight, and the creation of a global warming fund with millions for support to poor countries and emerging economies (Stern, 2007). Thus,eah government will struggle with the endemic implementation problems, as analysed in the theory of policy implementation (Wildavsky, 1979, 1987). Complete and successful implementation of policies is a figment of the imagination. Just look at Iran in order to understand the complexities of decarbonisation.

Countries may rely upon petroleum and gas mainly - see Iran (Figures 33 and 34). CO2 emissions have generally followed economic development in this giant country, although there seems to be a planning out recently, perhaps due to the international sanctions against its economy.

FIGURE 33. $\operatorname{Iran}\left(y=1,2229 x-4,91 ; R^{2}=0,98\right)$

LN

(CO2 emissions

$/ \mathrm{kg}$ )
GDP vs. CO2 emissions Iran 1990-2014

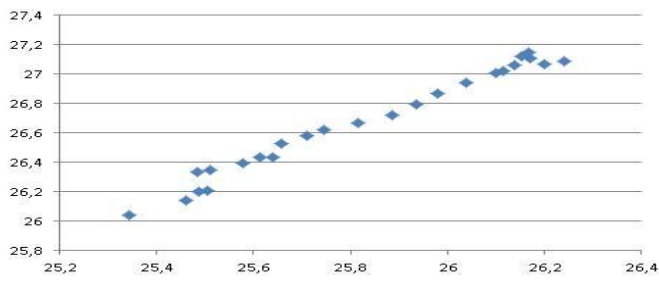

LN (GDP / (Constant Value 2005 USD)) 
Iran is together with Russia and Qatar the largest owner of natural gas deposits. But despite using coal in very small amounts, its $\mathrm{CO} 2$ emissions are high. Natural gas pollute less than oil and coal, but if released unburned it is very dangerous as a greenhouse gas.

\section{FIGURE 34.}

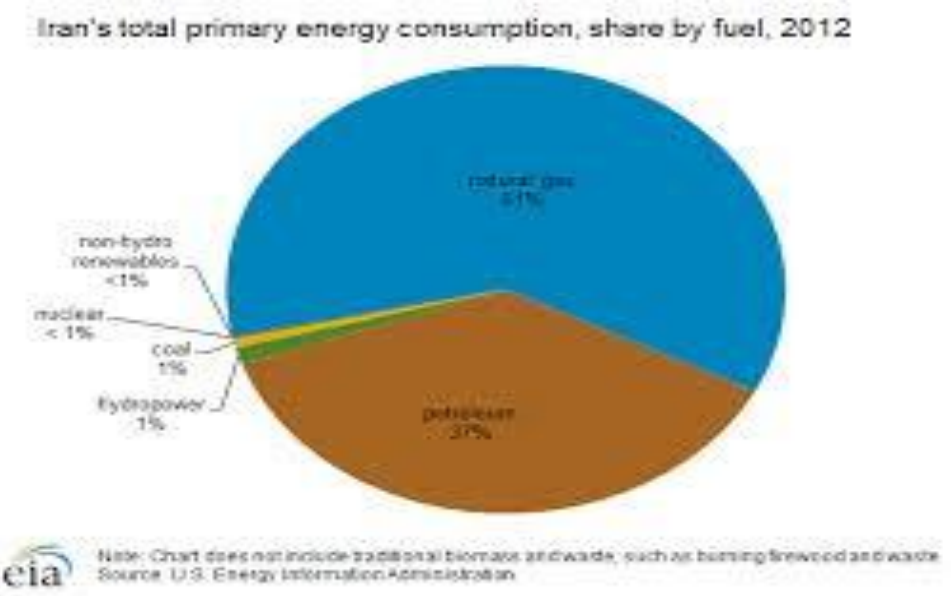

One understands why an emerging economy like Iran wants atomic power. It would allow them to sell their fossil fuels on the market. But the problems for international governance of this energy policy have been most costly in terms of transaction costs. Iran would defend its position with the economic growth argument (de Bruyn, 2012; Eriksson, 2013; Sachs, 2015). But it could also play the environmental card.

Thus, the implementation of COP21 global goals will be made more difficult and perhaps unfeasible when:

1) Countries are almost totally reliant upon solids or fossil fuels

2) They have little experience of modern renewables but employ traditional renewables heavily

3) They lack hydro or nuclear power

4) They need massive financial and technological assistance to shift energy sources

5) Their state is weakly institutionalised and enforce the rule of law in such a bad manner that there are few principal-agent restrictions upon governments

6) They suffer massive deaths for political violence in an anarchic condition.

It is not far fetched to state that the probability of implementation success for COP21 hinges not only upon the USA, Japan and the EU, but even more so upon the Third World, where conditions 1- 6 often apply.

\section{SOURCES AND LITERATURE}

Energy Information Administration $\quad$ (EIA) $2015 \quad$ Annual $\quad$ Energy (http://www.eia.gov/forecasts/aeo/index.cfm) 
World Bank national accounts data - data.worldbank.org)

OECD National Accounts data files

World Resources Institute CAIT Climate Data Explorer (cait.wri.org)

EU Joint Research Centre Emission Database for Global Atmospheric

Research - http://edgar.jrc.ec.europa.eu/overview.php

UN Framework Convention on Climate

http://unfccc.int/ghg_data/ghg_data_unfccc/time_series_annex_i/items/3814.php

International Energy Agency (IEA) (2015) World Energy Outlook (http://www.iea.org/bookshop/700-

World_Energy_Outlook_2015)

BP Energy Outlook 2015

United Nations Population Division: World Population Prospects, United Nations Statistical Division.

Population and Vital Statistics Report (various years), Census reports and other statistical publications from national statistical offices

Eurostat: Demographic Statistics

Secretariat of the Pacific Community: Statistics and Demography Program,

U.S.Census Bureau: International Database.

de Bruyn, S.M. (2012) Economic Growth and the Environment: An Empirical Analysis. Berlin: Springer.

Eriksson, C. (2013) Economic Growth and the Environment: An Introduction to the Theory. Oxford: OUP.

Mazmanian, D.A. and P. A. Sabatier (1989) Implementation and Public Policy Paperback. Lanham, MD: UPA.

Pressman, J. and A. Wildavsky (1973, 1984) Implementation. Berkeley: University of California Press.

Ramesh, J. (2015) Green Signals. Oxford: OUP.

Sabatier, P.A. (1998) "The advocacy coalition framework: revisions and relevance for Europe," in Journal of European Public Policy. Volume 5, Issue 1: pages 98-130.

Sabatier P.A. (1993), Policy Change and learning : An Advocacy Coalition Approach, Boulder, CO, Westview

Sachs, J. (August 10th, 2015) "Sustainable Development for Humanity's Future" (http://jeffsachs.org/2015/08/sustainable-development-for-humanitys-future/) Asian Development Bank.

Sachs, J. ( 2015) "Sustainable economies" (http://jeffsachs.org/2015/08/sustainable-development-for-humanitysfuture/).

Sachs, J (2015) The Age of Sustainable Development. New York: Columbia University Press.

Stern, N. (2007) The Economics of Climate Change. Oxford: OUP

Wildavsky, A. (1979, 1987) Speaking Truth to Power. Transaction Publishers. 